\title{
Spatial heterogeneity of macrofauna at northern California methane seeps: influence of sulfide concentration and fluid flow
}

\author{
Lisa A. Levin ${ }^{1, *}$, Wiebke Ziebis ${ }^{1,4}$, Guillermo F. Mendoza ${ }^{1}$, Valerie A. Growney ${ }^{1}$, \\ Michael D. Tryon ${ }^{2}$, Kevin M. Brown ${ }^{2}$, Chris Mahn ${ }^{3}$, Joris M. Gieskes ${ }^{3}$, \\ Anthony E. Rathburn ${ }^{1,5}$ \\ ${ }^{1}$ Integrative Oceanography Division, ${ }^{2}$ Geological Research Division, and ${ }^{3}$ Marine Research Division, \\ Scripps Institution of Oceanography, La Jolla, California 92093-0218, USA \\ ${ }^{4}$ Present address: Department of Biological Sciences, University of Southern California, Los Angeles, \\ California 90089-0371, USA \\ ${ }^{5}$ Present address: Department of Geography, Geology and Anthropology, Indiana State University, Terre Haute, \\ Indiana 47809, USA
}

\begin{abstract}
Relationships among fluid flow, sulfide concentration, sulfur bacteria and macrofaunal assemblages were examined at methane seeps on the northern California margin, near the mouth of the Eel River (512 to $525 \mathrm{~m}$ ). Over a 6 mo period, sediments covered with microbial mats exhibited significant but variable outflow of altered fluids, with no flow reversals. This fluid flow was associated with high porewater sulfide concentrations (up to $20 \mathrm{mM}$ ) and almost no oxygen penetration of sediments $(<0.1 \mathrm{~mm})$. Vesicomya pacifica (clam) bed and non-seep sediments exhibited little net fluid outflow and similar oxygen penetration ( 3 and $4 \mathrm{~mm}$, respectively); however, sulfide concentrations were higher in subsurface clam-bed sediments (up to $2 \mathrm{mM}$ ) than in non-seep sediments $(<200 \mu \mathrm{M}$ ). Macrofaunal densities did not differ among the 3 habitats (13800 to 16800 ind. $\mathrm{m}^{-2}$; $>300 \mu \mathrm{m}$ ), but biomass and diversity (no. species per core, $\left.\mathrm{E}\left(\mathrm{S}_{100}\right), H^{\prime}\right)$ were lower and composition varied in the sulfidic microbial mat sediments relative to clam-bed and non-seep sediments. The community in microbial mat-covered sediments consisted largely (82\%) of 6 species in the polychaete family Dorvilleidae, whereas the clam-bed and non-seep microhabitats supported a mixture of annelids, peracarid crustaceans, nemerteans, and mollusks. Vertical microprofiling of sulfide in animal cores indicated that most taxa avoid $\mathrm{H}_{2} \mathrm{~S}$ concentrations $>1 \mathrm{mM}$. However, sulfide-oxidizing filamentous bacteria, dorvilleid polychaetes and bivalves (mainly $V$. pacifica) exhibited highest densities at sulfide concentrations of 1 to $5 \mathrm{mM}$ sulfide. Horizontal and vertical patterns of sulfide availability have a strong influence on the fine-scale distribution, structure and composition of macrofaunal assemblages inhabiting methane seeps and must be accounted for when characterizing the microbiology and ecology of seep habitats.
\end{abstract}

KEY WORDS: Sulfur bacteria · Cold seep · Diversity · Dorvilleidae · Eel River · Macrobenthos · Microbial mat $\cdot$ Sulfide tolerance

\section{INTRODUCTION}

Marine sediments in nearshore and deeper continental margin settings characteristically exhibit a range of redox conditions, including zones of aerobic respiration, sulfate reduction and, in highly organic- rich sediments, methanogenesis (Aller 1982). Some of the most extreme conditions are found in areas where methane-laden fluids seep upwards, fueling syntrophic microbial reactions involving methane oxidation and sulfate reduction. These interactions yield exceptionally high porewater sulfide concentrations at 
methane seeps (Boetius et al. 2000, Valentine 2002). Because sulfide is toxic to most animals (Grieshaber \& Volkel 1998), we expect the community structure and distribution of infaunal assemblages in seep sediments to differ from those in surrounding non-sulfidic, nonseep sediments, and to be strongly influenced by sulfide availability (Bernhard et al. 2001, Sahling et al. 2002).

Methane seeps are broadly distributed along the tectonically active eastern Pacific margin (Kulm et al. 1986, Kennicut et al. 1989, Suess et al. 1989, 1998, Barry et al. 1996, Yun et al. 1999). Most research on the fauna of seeps has focused on the large megafauna (clams, tube worms, and mussels) (Sibuet \& Olu 1998, Van Dover et al. 2003), or on the microbiota (Buck \& Barry 1998, Hinrichs et al. 2000, Orphan et al. 2000). Investigators have described highly specialized, symbiont-bearing megafauna and complex microbial assemblages. Spatial variability in the abundance and composition of selected seep megafauna has been attributed to the influence of methane or sulfide (Barry et al. 1997, Wallman et al. 1997, Freytag et al. 2001). Responses of macro-infauna to seepage have only recently been explored (Sahling et al. 2002).

Infaunal macrobenthic and meiobenthic organisms can be abundant in seep sediments, but little is known about controls on their composition and distribution in these environments (Buck \& Barry 1998). The magnitude of fluid flow in seep environments is the primary control on the chemical profile with depth, which in turn is related to the distribution of fauna (Barry et al. 1997, Sahling et al. 2002). Low net flow rates of $\sim 1 \mathrm{~cm}$ $\mathrm{yr}^{-1}$ appear to provide sufficient methane from depth to fuel the near-surface communities while still allowing downward transport and mixing of oxygen- and sulfaterich seawater in the upper few centimeters of sediment. More intense fluid flow is associated with altered porewater composition and elevated sulfide concentrations that extend to the sediment surface, allowing the growth of surface microbial mats (Tryon \& Brown 2001, Torres et al. 2002).

Recently, Sahling et al. (2002) described macrofaunal communities $(>500 \mu \mathrm{m})$ associated with different seep habitats at Hydrate Ridge on the Oregon margin. They found differences in assemblage density, composition and diversity associated with Acharax, Calyptogena (Vesicomya) and bacterial-mat-dominated sediments that were strongly linked to gradients in sulfide flux and concentration. In a comparison of shallowwater seep and non-seep macrofaunal assemblages $(>300 \mu \mathrm{m})$ on the northern California shelf ( 35 to $55 \mathrm{~m}$ ), Levin et al. (2000) found only minor differences, with several species preferring or avoiding seeps, but no specialists. Preliminary analyses of infauna from $520 \mathrm{~m}$ in a $C$. (V.) pacifica bed revealed an assemblage char- acteristic of non-seep, California margin environments (Levin et al. 2000). However, this initial study focused on only 1 seep habitat-clam beds. It did not examine the community in relation to nearby non-seep sediments or bacterial-mat-covered sediments, and no geochemical data were collected.

Here we present a detailed characterization of seep macrofaunal community structure in relation to fluid flow and sediment porewater geochemistry for several different habitats. We ask: (1) Do sulfide concentrations, the abundance of large, filamentous sulfur bacteria, and infaunal community organization vary consistently among microbial mat, clam-bed and non-seep sediments? (2) Are these differences associated with patterns of fluid flow? (3) Are there macrofaunal taxa specifically associated with distinct seep environments? (4) Do microbial and animal distributions vary vertically within seep sediments in relation to local (millimeter-scale) porewater sulfide concentrations? We hypothesized that patterns of fluid flow create and regulate the geochemical environment, which in turn regulates community composition and dictates the horizontal and vertical distributions of macrofaunal organisms at methane seeps.

\section{MATERIALS AND METHODS}

Sediment sampling. Investigations were carried out in a region of extensive seepage $(\sim 500 \times 300 \mathrm{~m})$ located at 515 to $525 \mathrm{~m}$ on the northern California continental slope $\left(40^{\circ} 47.08^{\prime} \mathrm{N}, 124^{\circ} 35.68^{\prime} \mathrm{W}\right)$, offshore of the Eel River mouth. The site contained surficial microbial mats (Fig. 1A) and numerous patches of Vesicomya pacifica aggregations (Fig. 1B). The microbial mat habitat was often associated with release of methane bubbles and the occurrence of carbonate rocks. The general region is subject to episodic inputs of flood debris from land (Alexander \& Simoneau 1999, Leithold \& Hope 1999, Wheatcroft 2002) and sediments contain plant and wood-chip fragments (L. Levin unpubl. obs.). We made 3 CTD casts from the RV 'Thompson' during mid-October 2000 over the study area to measure bottom-water salinity, temperature and oxygen. Bottom sampling was conducted using the remotely operated vehicle (ROV) 'Jason' and control vehicle 'Medea', aboard the RV 'Thompson' from October 12 to 17,2000 . Samples of sediments, fauna and porewaters were collected in $8.3 \mathrm{~cm}$ diameter tube cores $(30 \mathrm{~cm}$ long) from habitats termed 'microbial mat', clam bed' and 'non-seep'. Non-seep areas were defined as sediments with no surface manifestation of seep fauna, bacteria or bubbles. Faunal samples included 5 microbial mat, 6 clam-bed and 4 non-seep cores (Fig. 2). All of the microbial mat cores were taken 

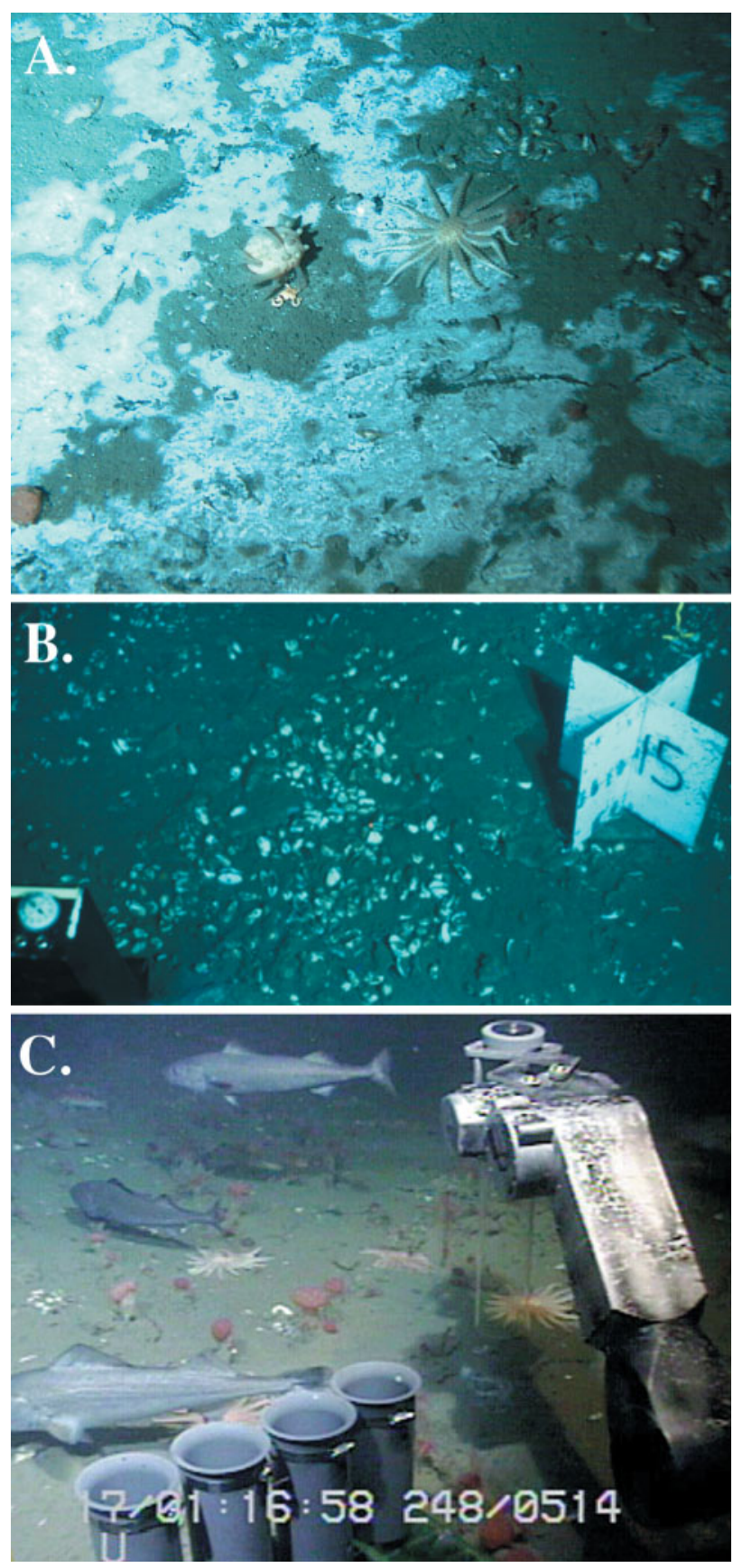

Fig. 1. Eel River margin, Northern California, $525 \mathrm{~m}$. (A) Microbial mat-covered sediments; (B) Vesicomya (Calyptogena) pacifica aggregations; (C) non-seep sediments

from the southern part of the study area, and thus represent less spatial coverage than the clam-bed and non-seep samples (Fig. 2). Core penetration varied with sediment characteristics, and often was limited to $10 \mathrm{~cm}$ depth. Once cores were on board ship, microprofiling of oxygen, sulfide and $\mathrm{pH}$ was carried out immediately. The same cores were subsequently pro- cessed for macrofauna. Cores were stored at 5 to $6^{\circ} \mathrm{C}$ (ambient bottom-water temperature) until processing.

Sample processing and measurements. Oxygen, sulfide and $\boldsymbol{p H}$ microprofiling: Oxygen and $\mathrm{H}_{2} \mathrm{~S}$ microgradients were measured in intact cores immediately after retrieval by means of amperometric microelectrodes. This was done prior to sectioning these same cores for quantification of bacteria and macrobenthos.

Vertical oxygen distributions in intact cores were measured by Clark-type microelectrodes provided with a built-in reference and a guard cathode (Jørgensen \& Revsbech 1989, Revsbech 1989). The electrodes were purchased from UNISENSE, Denmark, and had a sensing tip of 20 to $40 \mu \mathrm{m}$, a stirring sensitivity of $<2 \%$ and a $90 \%$ response time $\leq 1$ s. Electrode currents had a linear response to 0 and $100 \%$ airsaturation of $\mathrm{O}_{2}$. Linear calibration was done at $6^{\circ} \mathrm{C}$ in $100 \%$ saturated seawater $(35 \%)$ and nitrogen-purged seawater with $0 \%$ oxygen-saturation.

$\mathrm{H}_{2} \mathrm{~S}$ microgradients were measured using miniaturized amperometric sensors with an internal reference and a guard anode (Jeroschewsky et al. 1996). The sensors had a tip diameter of 40 to $60 \mu \mathrm{m}$. Calibration was performed after the sensor signal had stabilized during pre-polarization. A stock solution of $\mathrm{S}^{2-}(100 \mathrm{mM})$ was prepared by dissolving $\mathrm{Na}_{2} \mathrm{~S}$ in $\mathrm{N}_{2}$-flushed $0.1 \mathrm{M}$ $\mathrm{NaOH}$ in a closed container. The final concentration of stock solution was determined by standard analysis (Cline 1969). For the calibration curve, suitable amounts of the stock solution were injected into sealed serum vials containing oxygen-free calibration buffer (100 mM phosphate buffer, $\mathrm{pH}$ 7). The sensors were immersed in 3 to 4 different calibration solutions. These $\mathrm{H}_{2} \mathrm{~S}$ sensors were purchased from UNISENSE, Denmark, and have been successfully applied in marine ecological studies (Kuehl et al. 1998).

Oxygen and $\mathrm{H}_{2} \mathrm{~S}$ electrodes were attached to a micromanipulator mounted on a heavy stand. The sensors were connected to a high-sensitivity picoammeter (Unisense PA 2000); signals were amplified and data were recorded on a strip chart recorder or directly on a computer. Measurements were typically performed in vertical increments of $250 \mu \mathrm{m}$ for oxygen and $1 \mathrm{~mm}$ for $\mathrm{H}_{2} \mathrm{~S}$.

Parallel to the $\mathrm{H}_{2} \mathrm{~S}$ microprofiles, $\mathrm{pH}$ values were measured (5 $\mathrm{mm}$ vertical intervals) in the same cores, using a long needle combination $\mathrm{pH}$ electrode (Diamond General). The $\mathrm{H}_{2} \mathrm{~S}$ sensors detect the partial pressure of $\mathrm{H}_{2} \mathrm{~S}$ gas, which is only one component of the total sulfide equilibrium system. Thus, it is necessary to know the $\mathrm{pH}$ of the sample/calibration solution to calculate the total sulfide concentration (Jeroschewsky et al. 1996). We subjected 3 non-seep cores, 6 clam-bed cores and 4 microbial mat cores to microprofile measurements prior to sectioning for macrofauna. 


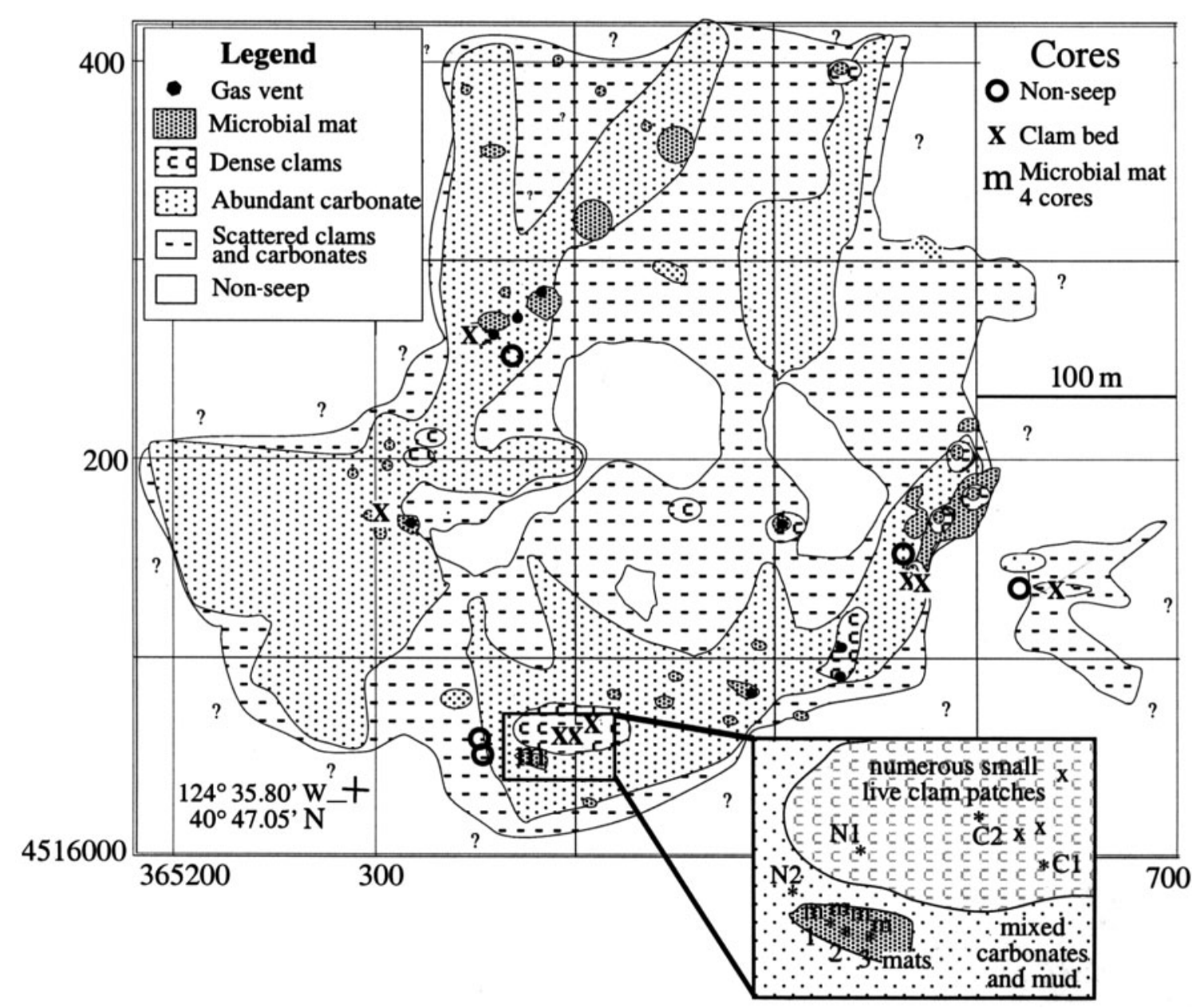

Fig. 2. Core locations and geological and biological features in the study area, Eel River margin, northern California, 500 to $525 \mathrm{~m}$. In inset, ${ }^{*}=$ Flux-meter positions; 1,2 and $3=$ microbial mat sediments; $\mathrm{C} 1$ and C2 = over clam beds, N1 and N2 = over non-seep sediments

Macrofauna and filamentous bacteria: Most cores to be analyzed for macrofauna and large sulfur bacteria were sectioned vertically at $0-1,1-2,2-5$, and 5-10 cm intervals. The fractions above $5 \mathrm{~cm}$ were preserved unsieved in $8 \%$ buffered formaldehyde, to permit analysis of macrofaunal and meiofaunal size taxa. The 5-10 cm fraction was sieved on a $300 \mu \mathrm{m}$ mesh prior to preservation. Several additional cores were sectioned at $0.5 \mathrm{~cm}$ intervals (to $2 \mathrm{~cm}$ ) and at $1-\mathrm{cm}$ intervals from 2 to $10 \mathrm{~cm}$, to provide higher resolution information about animal-sulfide relationships. These were preserved without sieving. Oxygen and sulfide profiles were generated for each of these high-resolution cores.

In the laboratory, all previously preserved macrofaunal core sediments were washed in freshwater on a $300 \mu \mathrm{m}$ mesh, and retained invertebrates and filamentous bacteria were sorted under a dissecting microscope at $12 \times$ magnification. Macrofaunal invertebrates were counted and identified to the lowest possible tax- onomic level (usually species) with the aid of a compound microscope. Bacterial filaments (>300 $\mu \mathrm{m})$ were sorted and counted. Sieving may have fragmented these large bacteria, so counts are considered to reflect relative vertical and horizontal patterns but biomass may provide a better indicator of absolute abundance. Sorted invertebrates and bacterial filaments were weighed on an analytical balance to determine wet weight biomass prior to transfer to $70 \%$ ethanol.

Habitat differences in macrofaunal density, biomass, taxonomic composition, species richness and other measures of diversity (Shannon information index $H^{\prime}$ [log-base 2], Pielou's evenness index $J^{\prime}$, and Rank 1 dominance, [R1D, as \% of most abundant species]) (Magurran 1988) were evaluated. All data were tested for normality with a Shapiro-Wilkes test. Habitat differences were analyzed for normally distributed data with a 1-way ANOVA and, if significant, with an a posteriori Tukey's honestly significantly different (HSD) test. Data were analyzed using non- 
parametric tests (Kruskal-Wallis with 1-way chi-square approximation) if they were not normally distributed, as transformations failed to normalize most data. JMP software (SAS Institute Inc.) was used to perform univariate statistical tests. Differences in representation of individual taxa were examined using a test based on sample size and the arcsine-transformed percentages (Sokal \& Rohlf 1969 p. 607). Multivariate analyses of community structure, including multidimensional scaling (MDS), analysis of similarities (ANOSIM) and SIMPER (similarity percentages) tests, were conducted with PRIMER Software (Primer-E Ltd.) (Clarke \& Warwick 1994). PRIMER was also used to calculate diversity indices $\left(H^{\prime}[\log\right.$ base 2$\left.], J^{\prime}, \mathrm{R} 1 \mathrm{D}\right)$. For both univariate and multivariate tests we decided not to employ corrections to experimentwise alpha for multiple testing since tests represent separate and clearly defined hypotheses (Quinn \& Keough 2002, Hurlbert \& Lombardi 2003). Rarefaction curves were generated with Biodiversity Pro (McAleece et al. 1997). Values given for biotic parameters are means $\pm 1 \mathrm{SE}$ unless indicated otherwise. Significance is assessed at $\alpha=0.05$.

Fluid-flow measurements. Measurements of fluid expulsion were made from October 14, 2000 to April 28, 2001, utilizing 7 chemical and aqueous transport (CAT) meters (Tryon et al. 2001). We placed 3 meters with the ROV on microbial mats, 2 in clam beds, and 2 in non-seep sediments (Fig. 2 inset). The meters are designed to quantify both inflow and outflow rates on the order of 0.01 to $1500 \mathrm{~cm} \mathrm{yr}^{-1}$. The CAT meter uses the dilution of a chemical tracer to measure flow through the outlet tubing at the top of the chamber. A tracer solution of similar density but different composition from the seep fluid is injected at a constant rate by 2 osmotic pumps into the water stream as it moves through the outlet tubing. These same pumps withdraw a sample of the seep fluid/tracer mixture (in this case scandium and rubidium) from downstream of the tracer injection port, giving a serial record of the tracer dilution. Upon recovery of the instruments, the coils are subsampled at appropriate intervals, and tracer concentration is analyzed via inductively coupled plasma-optical emission spectrometry (ICP-OES).

\section{RESULTS}

\section{Visual site observations}

A thorough site survey was accomplished early in the first cruise utilizing video and sonar observations from the ROV 'Jason', correlated with track logs from Jason's transponder array (long baseline navigation) accurate to $\pm 1 \mathrm{~m}$ (Fig. 2). Indications of recent and paleo methane seepage (Hovland 2002) were observed over $70 \%$ of the area surveyed, including abundant and widespread small clam (Vesicomya pacifica) aggregations, carbonates, less extensive surficial microbial mats and local venting of free methane (Fig. 2). Prior seep activity was indicated by the preponderance of carbonate pavements and low ridges (less than a few meters high) of more rugged carbonate blocks. Large chemoherms, massive carbonates built up due to bacterial mediated $\mathrm{CO}_{2}$ production from methane and subsequent precipitation of $\mathrm{CaCO}_{3}$ (sensu Bohrmann et al. 1998), were not observed.

The majority of the Vesicomya pacifica were scattered as $\sim 10$ to $50 \mathrm{~cm}$ diameter aggregations spaced 1 to $5 \mathrm{~m}$ apart. Microbial mat sites were typically much rarer and were often manifested as small $(10$ to $30 \mathrm{~cm})$ patches developed along cracks in carbonates and less commonly in patchy sedimented sites; 1 large mat (a mosaic of patches several meters in diameter) was the site of fluid-flow measurements and coring. Larger aggregations of $V$. pacifica were also observed locally (3 to 10 m diameter) (Fig. 2).

Gas vents typically were observed to consist of several small, dispersed bubbling sites several meters apart, from which intermittent gas release occurred through cracks or at edges of carbonate blocks. Vent sites were generally confined to regions dominated by carbonates. The gas-vent sites typically did not have large microbial mats directly associated with them, although small microbial mats and scattered clam patches occurred locally. Overall, the hydrologic activity in this region was typified by a diffuse network of many small (centimeterscale) seeps and vents, with diffuse widespread activity over length scales of 100s of meters.

\section{Fluid flow}

CAT meter fluid-flow measurements at microbial mat sites revealed significant outflow of altered fluids, with no flow reversals (Fig. 3). During periods of flow, the average rate was $10 \mathrm{~cm} \mathrm{yr}^{-1}$. The microbial mat sites, however, exhibited no flow for the first 2 to $3 \mathrm{mo}$, followed by highly variable outflow for the remaining 4 mo. The altered fluids expelled at these sites were typical of pore fluids in the microbial mat area ( $\mathrm{J}$. Gieske \& C. Mahn unpubl. data). No difference was observed between fluid flow at clam bed and non-seep sites. These sites exhibited highly variable flow with rapid flow reversals believed to be tidally generated (Tryon et al. 2002). While these instruments cannot resolve flow rates in an environment of rapid flowreversals, we can qualitatively determine if there is net upflow, downflow, or no net flow (Tryon \& Brown 2001). Overall net flow rates from the clam bed and non-seep habitats were low $\left(<1 \mathrm{~cm} \mathrm{yr}^{-1}\right)$. 


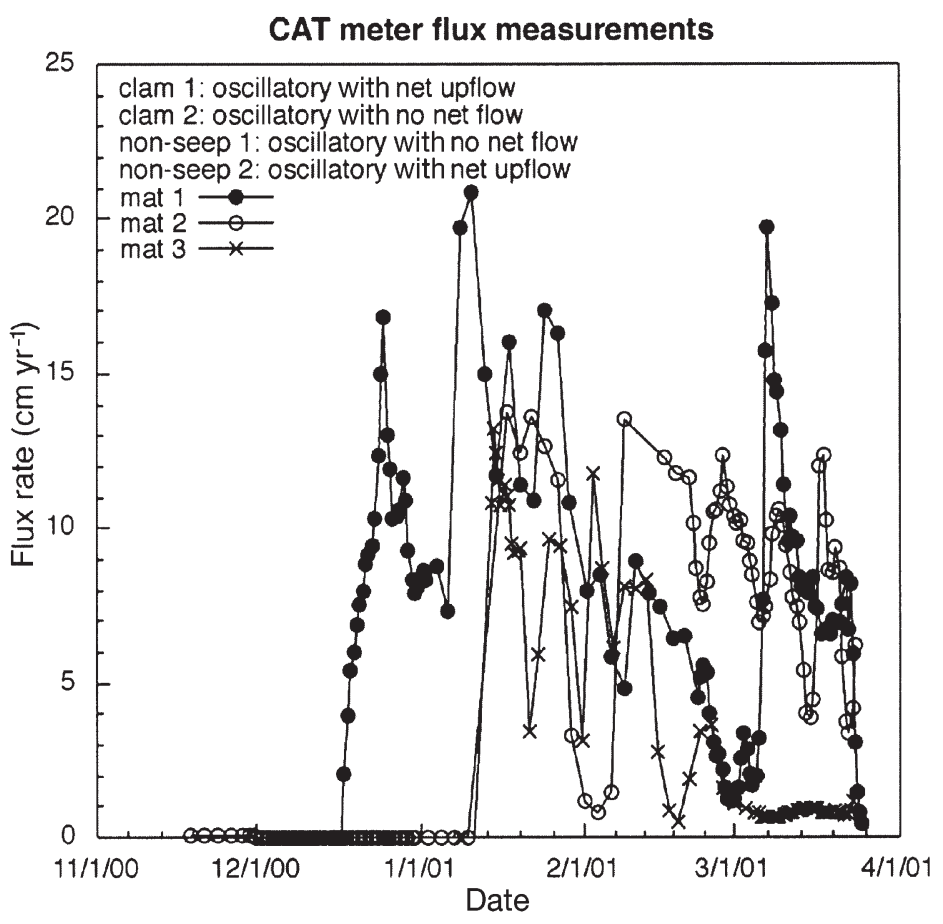

Fig. 3. Fluid-flow determined by CAT (chemical and aqueous transport) fluid flux meters. Dates are given as mo/d/yr. See 'Materials and methods' for instrument description

\section{Sediment porewater geochemistry}

The microbial mat, clam bed and nonseep sediments exhibited geochemical and seepage differences in the upper $10 \mathrm{~cm}$ of the sediment column. Oxygen penetration was deepest in non-seep sediments $(4 \mathrm{~mm})$, but was similar to clam bed sediments ( $3 \mathrm{~mm})$, with a typical diffusive concentration profile (Jørgensen \& Revsbech 1985). In contrast, there was almost no oxygen penetrating microbial mat sediments $(<0.1 \mathrm{mM})$ (Fig. 4).

Each of the habitats studied exhibited a distinctive sulfide profile (Fig. 4). Sulfide concentration was one order of magnitude higher in clambed than non-seep sediments and in microbial mat than clam bed sediments. High concentrations of sulfide (with core maxima of 14 to $20 \mathrm{mM}$ ), were measured throughout microbial mat cores and reached the sediment-water interface. The sulfide profiles of the microbial mat core suggest a strong sulfide flux from below (Fig. 4). In the clam beds, no sulfide was detected in the upper $4 \mathrm{~cm}$, the depth to which we observed the Vesicomya pacifica foot to extend in tube cores. Below this zone, sulfide increased with depth to maximum concentrations of up to $2 \mathrm{mM}$ at $\sim 9 \mathrm{~cm}$ depth, indicating a well-defined zone of local sulfide production by sulfate reduction (Fig. 4). In non-seep sediments, sulfide was absent or occurred at a low concentration $(<0.2 \mathrm{mM})$ in the upper 3 to $7 \mathrm{~cm}$ sediment depth (Fig. 4). The microelectrode data reveal among-microhabitat differences in the amount and distribution of 'sulfide-free' sediment (here defined as $<0.1 \mathrm{mM} \mathrm{H}_{2} \mathrm{~S}$ ). This zone was restricted to the surface-water interface in microbial mat sediments, to the upper $4 \mathrm{~cm}$ in clam-bed sediments, and spanned the entire sediment column that was sampled (to $12 \mathrm{~cm}$ ) in most non-seep sediments (Fig. 4).

\section{Overlying water and sediment properties}

During the study, bottom-water temperature ranged from 5.28 to $5.75^{\circ} \mathrm{C}$, salinity from 33.2 to 33.6 , and oxygen concentration from 0.24 to $0.48 \mathrm{ml} \mathrm{l}^{-1}$. Previous analyses of replicate sediment samples collected from clam-bed sediments at this site in 1997 yielded average sediment values of $12.4 \% \mathrm{CaCO}_{3}, 0.97 \%$ organic C, $0.06 \%$ organic $\mathrm{N}$, and a C:N ratio of 16.8 (Levin et al. 2000). No additional sediment analyses were conducted in 2000 .

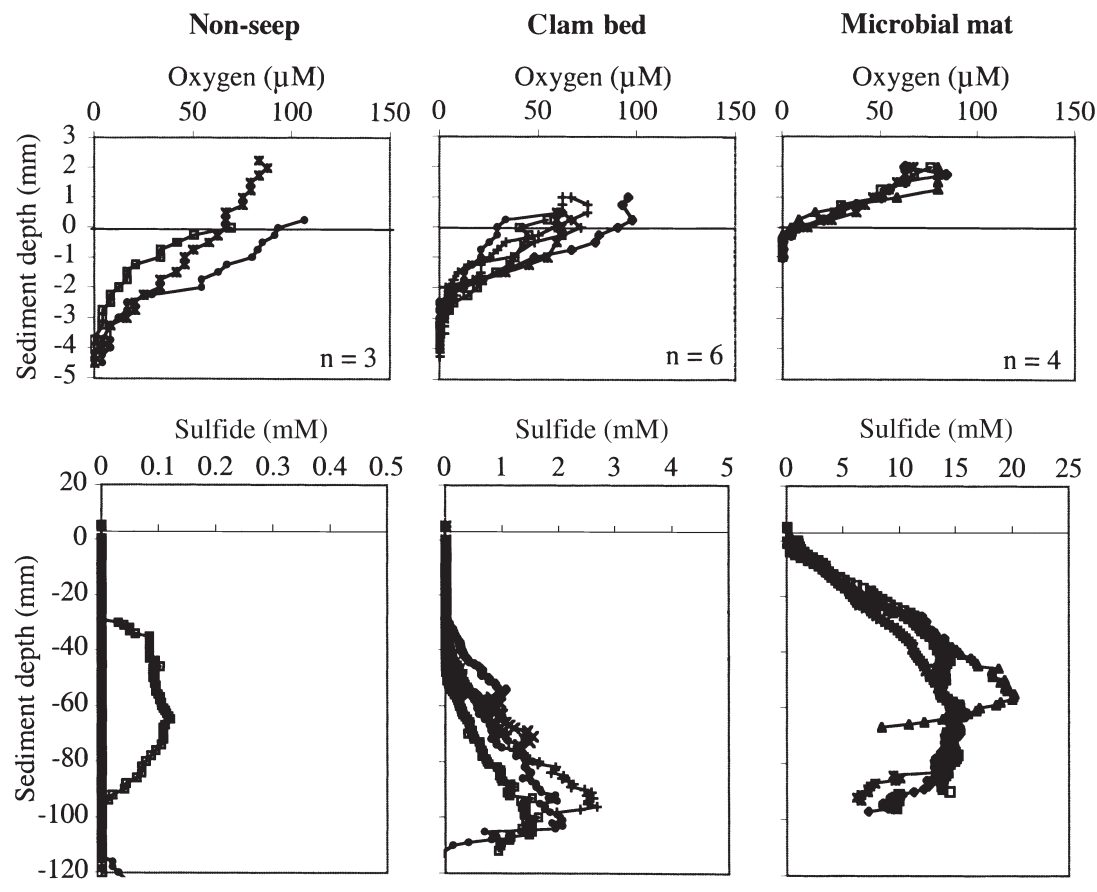

Fig. 4. Microelectrode profiles in microbial mat, clam-bed and non-seep sediments of oxygen and sulfide. Note different scales on various sulfide plots 


\section{Megafauna}

Most of the study region supported epifaunal communities dominated by cnidarians (Anthomastus ritteri), ophiuroids, asteroids (Rathbunaster californicus), and large demersal nekton populations comprised largely of sablefish Anoplopoma fimbria (Fig. 1). Microbial mats (Fig. 1A) and Vesicomya pacifica aggregations (Fig. 1B) were the primary surface manifestation of methane seepage. The vesicomyid clams at Pacific methane seeps form a species complex, but molecular studies confirm the identity of $V$. pacifica in the Eel River region (Goffredi et al. 2002). Microbial mats were comprised largely of Beggiatoa-like filamentous bacteria. Shipboard video-feed observations of the sea floor revealed large gastropods Neptunea sp. feeding on $V$. pacifica. Sablefish were common in the work area and hovered near the ROV during dives. They were observed stirring up and grabbing mouthfuls of sediment, suggesting that they consume bottom fauna at the seeps.

\section{Filamentous bacteria}

Counts of filamentous sulfur bacteria (>300 $\mu \mathrm{m}$ ) in each core yielded a consistent pattern: highest values in microbial mat sediments $\left(3428 \pm 970\right.$ filaments $\left.\mathrm{m}^{-2}\right)$, intermediate values in the clam beds $(1442 \pm 381$ filaments $\mathrm{m}^{-2}$ ), and lowest values in the non-seep sediments $(270 \pm 270$ filaments $\mathrm{m}^{-2}$ ). Microbial-mat filament densities (per 10-cm-deep tube core) were higher than those in non-seep sediments, but clam bed densities did not differ from either of the other 2 habitats (Kruskal-Wallis: $\mathrm{p}=0.024$ ). Total biomass of filamentous bacteria (per 10-cm-deep tube core) exhibited a similar pattern, with highest biomass in the mats $\left(2.25 \pm 1.22 \mathrm{~g} \mathrm{~m}^{-2}\right)$, lowest in non-seep sediments $\left(0.25 \pm 0.25 \mathrm{~g} \mathrm{~m}^{-2)}\right.$ and intermediate values in the clam bed $\left(1.80 \pm 1.01 \mathrm{~g} \mathrm{~m}^{-2}\right)$, but differences among habitats were not significant (Kruskal-Wallis: $\mathrm{p}=0.140$ ).

\section{Macrofaunal community variation in seep habitats}

Abundance and composition

Despite strong variation in geochemical conditions, total macrofaunal densities did not vary among seep habitats (1-way
ANOVA: $p=0.775)$. Average densities were $13834 \pm$ 4766 individuals (ind.) $\mathrm{m}^{-2}$ in microbial mat sediments, $16892 \pm 2277$ ind. $\mathrm{m}^{-2}$ in clam-bed sediments, and $16552 \pm 2112$ ind. $\mathrm{m}^{-2}$ in non-seep sediments. There was however, significantly less macrofaunal biomass in the mat sediments $\left(1.73 \pm 0.40 \mathrm{~g} \mathrm{~m}^{-2}\right)$, than in clam bed $\left(23.76 \pm 11.21 \mathrm{~g} \mathrm{~m}^{-2}\right)$ or non-seep sediments $(23.80 \pm$ $8.53 \mathrm{~g} \mathrm{~m}^{-2}$ ) (Kruskal-Wallis: $\mathrm{p}=0.011$ ).

Strong differences in macrofaunal composition were observed between the microbial mat sediments and the other 2 habitats. Annelids were the dominant phylum in each habitat (Fig. 5A), comprising 89.0, 52.2, and $47.5 \%$ of the macrofauna in microbial mat, clam bed, and non-seep sediments, respectively. Microbial mat communities consisted largely of 5 species of dorvilleid polychaetes ( $82 \%$ of the total); the remainder included other annelids (6\%), with molluscs, peracarid crustaceans nemerteans, and turbellarians each comprising less than $5 \%$ of the fauna (Fig. 5A, Table 1). Composition of the clam bed and non-seep communities was remarkably similar (Fig. 5A), with greater representation of peracarid crustaceans $(22.3$ and $27.9 \%$ [arcsine test for percentage differences: both $\mathrm{p}<0.0001])$, mollusks $(9.7 \%$ [ $p=0.056]$ and $6.3 \%$ $[p=0.124]$, respectively), and nemerteans $(13.3 \%$

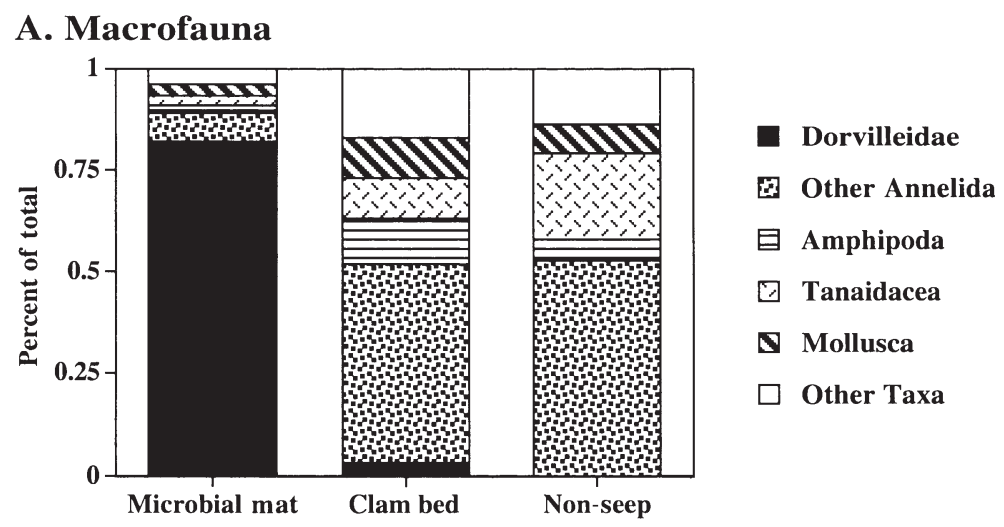

\section{B. Annelida}

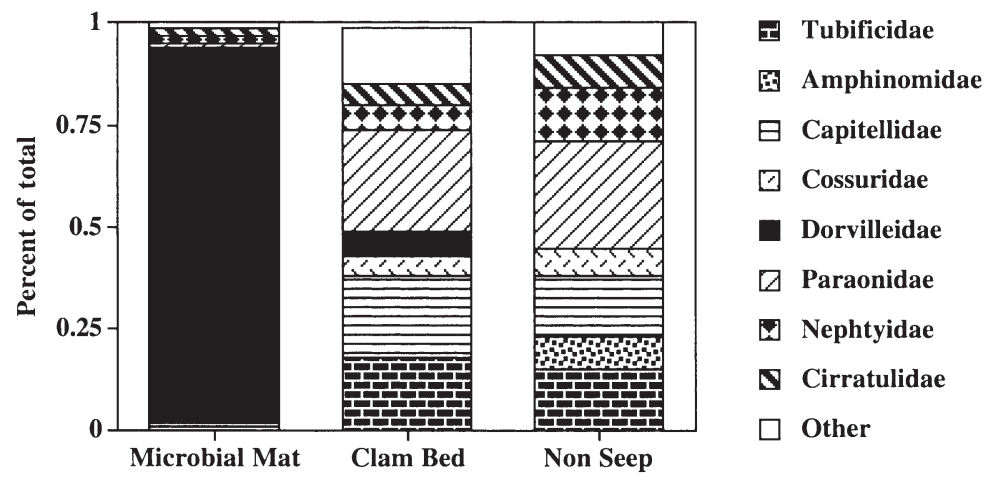

Fig. 5. Macrofaunal $(>300 \mu \mathrm{m})$ taxonomic composition. (A) Major taxa (B) annelid family composition 
Table 1. Mean (SE) density of macrofauna (>300 $\mu \mathrm{m})$ per core $\left(54.08 \mathrm{~cm}^{2} \times 10 \mathrm{~cm}\right.$ deep) in clam bed (cb) microbial mat (mm), and non-seep (ns) habitats. Differences among microbial mat, clam bed and non-seep habitats were tested with a Kruskal-Wallis test resulting in a chi-square statistic. Probabilities $<0.05$ are indicated for each taxon. Directions of differences are indicated as (a) $n s>c b+m m$; (b) $m m>c b+n s$; (c) cb >ns + mm; (d) ns + mm > cb; (e) cb + ns > mm; Prop.: proportion

\begin{tabular}{|c|c|c|c|c|c|c|c|}
\hline \multirow{2}{*}{ Species } & \multicolumn{2}{|c|}{ Clam bed } & \multicolumn{2}{|c|}{ Microbial mat } & \multicolumn{2}{|c|}{ Non-seep } & \multirow{2}{*}{$\begin{array}{c}\text { Kruskal- } \\
\text { Wallis } \\
\text { prob. }\end{array}$} \\
\hline & Avg. (SE) & $\begin{array}{l}\text { Prop. } \\
\text { of total }\end{array}$ & Avg. (SE) & $\begin{array}{l}\text { Prop. } \\
\text { of total }\end{array}$ & Avg. (SE) & $\begin{array}{l}\text { Prop. } \\
\text { of total }\end{array}$ & \\
\hline \multicolumn{8}{|l|}{ ANNELIDA } \\
\hline \multicolumn{8}{|l|}{ Oligochaeta } \\
\hline \multicolumn{8}{|l|}{ Tubificidae } \\
\hline Unid. tubificid & 0 & 0.0 & 0 & 0.0 & $7.00(5.74)$ & 0.083 & 0.0525 (a) \\
\hline Tectidrilus cf. diversus & $8.50(2.65)$ & 0.093 & 0 & 0.0 & 0 & 0.0 & $0.0068(\mathrm{c})$ \\
\hline \multicolumn{8}{|l|}{ Hirudinea } \\
\hline Unid. hirudinean & $0.17(0.17)$ & 0.002 & 0 & 0.0 & $0.25(0.25)$ & 0.003 & \\
\hline Polychaeta & & & & & & & \\
\hline Amphinomidae & & & & & & & \\
\hline $\begin{array}{l}\text { Capitellidae } \\
\text { Mediomastus spp. }\end{array}$ & $9.67(4.29)$ & 0.106 & $0.80(0.49)$ & 0.011 & $6.75(2.06)$ & 0.080 & \\
\hline Maldanidae & & & & & & & \\
\hline Maldanid sp. a & $1.33(0.76)$ & 0.015 & $0.20(0.20)$ & 0.003 & $0.50(0.29)$ & 0.006 & \\
\hline Nicomache sp. a & 0 & 0.0 & 0 & 0.0 & 0 & 0.0 & \\
\hline Cossuridae & & & & & & & \\
\hline Cossura spp. & $2.50(0.56)$ & 0.027 & $0.60(0.60)$ & 0.008 & $3.00(1.78)$ & 0.035 & \\
\hline Dorvilleidae & & & & & & & \\
\hline Ophryotrocha platykephale & 0 & 0.0 & $45.6(17.82)$ & 0.625 & 0 & 0.0 & $0.0013(\mathrm{~b})$ \\
\hline Pseudophryotrocha cf. serrata & 0 & 0.0 & $5.80(1.98)$ & 0.079 & 0 & 0.0 & $0.0013(\mathrm{~b})$ \\
\hline Ophryotrocha sp. 1 & 0 & 0.0 & $0.60(0.24)$ & 0.008 & 0 & 0.0 & 0.0302 (b) \\
\hline Ophryotrocha nr. platykephale & 0 & 0.0 & $3.40(1.91)$ & 0.047 & 0 & 0.0 & 0.0318 (b) \\
\hline Parougia sp. $\mathrm{n}$ & $1.50(1.12)$ & 0.016 & $1.60(1.03)$ & 0.022 & 0 & 0.0 & \\
\hline Exallopus sp. n & $1.33(1.33)$ & 0.015 & 0 & 0.0 & 0 & 0.0 & \\
\hline Unid. Dorvilleid & $0.17(0.17)$ & 0.002 & $2.60(1.63)$ & 0.036 & 0 & 0.0 & $0.0229(\mathrm{~b})$ \\
\hline Lumbrineridae & & & & & & & \\
\hline Lumbrinerid sp. a & $0.17(0.17)$ & 0.002 & 0 & 0.0 & $0.25(0.25)$ & 0.003 & \\
\hline Opheliidae & & & & & & & \\
\hline Ophelina sp. a & $0.17(0.17)$ & 0.002 & 0 & 0.0 & 0 & 0.0 & \\
\hline Ophelina acuminata & 0 & 0.0 & 0 & 0.0 & 0 & 0.0 & \\
\hline Orbiniidae & & & & & & & \\
\hline Naineris cf. grubei & $0.17(0.17)$ & 0.002 & 0 & 0.0 & 0 & 0.0 & \\
\hline Paraonidae & & & & & & & \\
\hline Paraonid sp. a & $2.67(1.85)$ & 0.029 & 0 & 0.0 & 0 & 0.0 & \\
\hline Paraonid sp. b & $2.83(1.38)$ & 0.031 & 0 & 0.0 & $0.50(0.50)$ & 0.006 & \\
\hline Levinsenia oculata & $5.83(4.34)$ & 0.064 & 0 & 0.0 & $7.75(1.80)$ & 0.091 & 0.022 (a) \\
\hline Aricidea (Acmira) catherinae & 0 & 0.0 & 0 & 0.0 & $0.50(0.50)$ & 0.006 & \\
\hline Levinsenia sp. juv. & $0.50(0.34)$ & 0.005 & $0.60(0.40)$ & 0.008 & $3.00(1.22)$ & 0.035 & \\
\hline Phyllodocidae & & & & & & & \\
\hline Phyllodoce sp. a & $0.33(0.21)$ & 0.004 & 0 & 0.0 & $0.50(0.29)$ & 0.006 & \\
\hline Polynoidae & & & & & & & \\
\hline Harmothoe fragilis & $0.50(0.34)$ & 0.005 & 0 & 0.0 & 0 & 0.0 & \\
\hline Glyceridae & & & & & & & \\
\hline Glycerid sp. a & $0.17(0.17)$ & 0.002 & 0 & 0.0 & $0.25(0.25)$ & 0.003 & \\
\hline Goniadidae & & & & & & & \\
\hline Goniada cf. litorea & $0.17(0.17)$ & 0.002 & 0 & 0.0 & $0.25(0.25)$ & 0.003 & \\
\hline Nephtyidae & & & & & & & \\
\hline Nephtys cornuta & $2.67(0.88)$ & 0.029 & $1.60(0.24)$ & 0.022 & $5.75(1.11)$ & 0.068 & $0.0392(\mathrm{a})$ \\
\hline Nereididae & & & & & & & \\
\hline Nereis sp.a & $0.17(0.17)$ & 0.002 & 0 & 0.0 & 0 & 0.0 & \\
\hline Sphaerodoridae & & & & & & & \\
\hline Sphaerodorid sp.a & $0.17(0.17)$ & 0.002 & 0 & 0.0 & $0.25(0.25)$ & 0.003 & \\
\hline Syllidae & & & & & & & \\
\hline Syllidae sp. b & $0.17(0.17)$ & 0.002 & 0 & 0.0 & $0.25(0.25)$ & 0.003 & \\
\hline Sphaerosyllis sp. b & 0 & 0.0 & 0 & 0.0 & $0.25(0.25)$ & 0.003 & \\
\hline Cirratulidae & & & & & & & \\
\hline Aphelochaeta sp. $\mathrm{h}$ & $0.83(0.83)$ & 0.009 & 0 & 0.0 & $1.75(1.03)$ & 0.021 & \\
\hline Chaetozone sp. h & $0.17(0.17)$ & 0.002 & 0 & 0.0 & $1.25(1.25)$ & 0.014 & \\
\hline Aphelochaeta cf. monilaris & $0.83(0.54)$ & 0.009 & 0 & 0.0 & $0.25(0.25)$ & 0.003 & \\
\hline Unid. cirratulid juv. & $0.67(0.33)$ & 0.007 & $1.00(0.45)$ & 0.014 & $0.50(0.29)$ & 0.006 & \\
\hline Spionidae & & & & & & & \\
\hline Prionospio (Minuspio) lighti & $0.83(0.40)$ & 0.009 & 0 & 0.0 & 0 & 0.0 & \\
\hline Terebellidae & & & & & & & \\
\hline Terebellid sp. c & $0.67(0.33)$ & 0.007 & 0 & 0.0 & 0 & 0.0 & \\
\hline Artacama cf. coniferi & $0.17(0.17)$ & 0.002 & 0 & 0.0 & 0 & 0.0 & \\
\hline Trichobranchidae & & & & & & & \\
\hline Terebellides sp. a & $0.50(0.22)$ & 0.005 & 0 & 0.0 & 0 & 0.0 & \\
\hline Ampharetidae & & & & & & & \\
\hline Ampharete sp. a & 0 & 0.0 & $0.20(0.20)$ & 0.003 & 0 & 0.0 & \\
\hline Unid. ampharetid (juv) & 0 & 0.0 & $0.20(0.20)$ & 0.003 & 0 & 0.0 & \\
\hline Unknown terebelliform & $0.17(0.17)$ & 0.002 & 0 & 0.0 & $0.50(0.50)$ & 0.006 & \\
\hline Unknown spioniform & 0 & 0.0 & 0 & 0.0 & $0.25(0.25)$ & 0.003 & \\
\hline
\end{tabular}


Table 1 (continued)

\begin{tabular}{|c|c|c|c|c|c|c|c|}
\hline \multirow[t]{2}{*}{ Species } & \multicolumn{2}{|c|}{ Clam bed } & \multicolumn{2}{|c|}{ Microbial mat } & \multicolumn{2}{|c|}{ Non-seep } & \multirow{2}{*}{$\begin{array}{c}\text { Kruskal- } \\
\text { Wallis } \\
\text { prob. }\end{array}$} \\
\hline & Avg. (SE) & $\begin{array}{l}\text { Prop. } \\
\text { of total }\end{array}$ & Avg. (SE) & $\begin{array}{l}\text { Prop. } \\
\text { of total }\end{array}$ & Avg. (SE) & $\begin{array}{l}\text { Prop. } \\
\text { of total }\end{array}$ & \\
\hline \multicolumn{8}{|l|}{ Nerillidae } \\
\hline Nerillid sp. a & $0.33(0.21)$ & 0.004 & 0 & 0.0 & 0 & 0.0 & \\
\hline Flabelligeridae & & & & & & & \\
\hline Pherusa cf. neopapillata & $0.33(0.21)$ & 0.004 & 0 & 0.0 & 0 & 0.0 & \\
\hline NEMERTA & & & & & & & \\
\hline Unid. nemertean & $12.17(3.29)$ & 0.134 & $1.20(1.20)$ & 0.016 & $9.50(3.23)$ & 0.112 & $0.0171(\mathrm{c})$ \\
\hline \multicolumn{8}{|l|}{ PLATYELMINTHA } \\
\hline Turbellaria & & & & & & & \\
\hline Unid. turbellarian & $0.17(0.17)$ & 0.002 & $1.00(0.63)$ & 0.014 & 0 & 0.0 & \\
\hline \multicolumn{8}{|l|}{ ARTHROPODA } \\
\hline Crustacea & & & & & & & \\
\hline Amphipoda & & & & & & & \\
\hline Gammaridea & & & & & & & \\
\hline Rhachotropis (?) & 0 & 0.0 & $0.20(0.20)$ & 0.003 & 0 & 0.0 & \\
\hline Bathymedon (?) & 0 & 0.0 & $0.20(0.20)$ & 0.003 & 0 & 0.0 & \\
\hline Rhachotropis clemens & $1.33(0.98)$ & 0.015 & 0 & 0.0 & 0 & 0.0 & \\
\hline Harpiniopsis galera & $1.50(0.56)$ & 0.016 & 0 & 0.0 & 0 & 0.0 & $0.0243(\mathrm{c})$ \\
\hline Protomedeia sp. (?) & $1.83(1.27)$ & 0.020 & 0 & 0.0 & 0 & 0.0 & \\
\hline Cephalophoxoides homilis & $1.17(0.65)$ & 0.013 & 0 & 0.0 & $0.25(0.25)$ & 0.003 & \\
\hline Harpiniopsis spp. & $0.83(0.47)$ & 0.009 & $0.20(0.20)$ & 0.003 & $1.00(0.71)$ & 0.012 & \\
\hline Harpiniopsis opistomata & $0.17(0.17)$ & 0.002 & 0 & 0.0 & $0.25(0.25)$ & 0.003 & \\
\hline Corophioidea spp. & $0.17(0.17)$ & 0.002 & 0 & 0.0 & $0.25(0.25)$ & 0.003 & \\
\hline Photis spp. & $0.83(0.54)$ & 0.009 & 0 & 0.0 & $0.50(0.50)$ & 0.006 & \\
\hline Gammaridea juv. & $0.33(0.21)$ & 0.004 & 0 & 0.0 & 0 & 0.0 & \\
\hline Unid. gammarideans & $0.50(0.34)$ & 0.005 & 0 & 0.0 & 0 & 0.0 & \\
\hline Ampelisca usocalae & $0.67(0.49)$ & 0.007 & 0 & 0.0 & $1.25(0.63)$ & 0.015 & \\
\hline Byblis spp. & $0.17(0.17)$ & 0.002 & 0 & 0.0 & $0.25(0.25)$ & 0.003 & \\
\hline Caprellidea & & & & & & & \\
\hline Tritella sp. & 0 & 0.0 & $0.60(0.40)$ & 0.008 & 0 & 0.0 & \\
\hline Unid. caprellid & $0.50(0.50)$ & 0.005 & 0 & 0.0 & 0 & 0.0 & \\
\hline Isopoda & & & & & & & \\
\hline Munnogonium sp. (?) & $0.17(0.17)$ & 0.002 & 0 & 0.0 & $0.50(0.50)$ & 0.006 & \\
\hline Pleurogonium sp. (?) & $0.17(0.17)$ & 0.002 & $0.20(0.20)$ & 0.003 & 0 & 0.0 & \\
\hline Cumacea & & & & & & & \\
\hline Campylaspis sp. & 0 & 0.0 & $0.40(0.4)$ & 0.005 & 0 & 0.0 & \\
\hline Eudorella pacifica & $0.67(0.33)$ & 0.007 & 0 & 0.0 & 0 & 0.0 & \\
\hline ?Hemilamprops sp. b & $0.17(0.17)$ & 0.002 & 0 & 0.0 & 0 & 0.0 & \\
\hline Unid. cumacean & 0 & 0.0 & 0 & 0.0 & $1.00(0.58)$ & 0.012 & \\
\hline Tanaidacea & & & & & & & \\
\hline Tanaella sp. & $1.67(0.56)$ & 0.018 & $1.00(0.63)$ & 0.014 & $0.25(0.25)$ & 0.003 & \\
\hline Araphura spp. & $5.00(2.31)$ & 0.055 & $0.20(0.20)$ & 0.003 & $0.75(0.75)$ & 0.009 & 0.0361 \\
\hline Unid tanaid juv. & $1.5(0.56)$ & 0.016 & $0.60(0.40)$ & 0.008 & $1.50(0.96)$ & 0.018 & \\
\hline Unid tanaid & $0.67(0.49)$ & 0.007 & 0 & 0.0 & $15(8.55)$ & 0.177 & 0.0048 (a) \\
\hline Mysidacea & & & & & & & \\
\hline Pseudomma sp. & $0.67(0.49)$ & 0.007 & 0 & 0.0 & 0 & 0.0 & \\
\hline MOLLUSCA & & & & & & & \\
\hline Aplacophora & & & & & & & \\
\hline Unid. aplacophoran & 0 & 0.0 & 0 & 0.0 & $0.25(0.25)$ & 0.003 & \\
\hline Bivalvia & & & & & & & \\
\hline Calyptogena sp. & $0.83(0.48)$ & 0.009 & 0 & 0.0 & $0.5(0.29)$ & 0.006 & \\
\hline Mysella spp. & 0 & 0.0 & $0.60(0.40)$ & 0.008 & 0 & 0.0 & \\
\hline Rochefortia sp. & $0.67(0.42)$ & 0.007 & 0 & 0.0 & 0 & 0.0 & \\
\hline Axinopsida serricata & $0.50(0.34)$ & 0.005 & 0 & 0.0 & 0 & 0.0 & \\
\hline Adontorhina cyclia & $0.33(0.33)$ & 0.004 & 0 & 0.0 & 0 & 0.0 & \\
\hline Bivalve sp.g & $0.17(0.17)$ & 0.002 & 0 & 0.0 & 0 & 0.0 & \\
\hline Bivalve sp. bc & $0.33(0.21)$ & 0.004 & $0.40(0.24)$ & 0.005 & 0 & 0.0 & \\
\hline Unid. bivalve juv. & 0 & 0.0 & $0.80(0.20)$ & 0.011 & $1(0.41)$ & 0.012 & 0.0201 (d) \\
\hline Gastropoda & & & & & & & \\
\hline Provanna sp. & $1.67(0.92)$ & 0.018 & 0 & 0.0 & $0.75(0.48)$ & 0.009 & \\
\hline Odostomia sp. & $2.83(0.94)$ & 0.031 & 0 & 0.0 & $1.00(0.71)$ & 0.012 & $0.0302(\mathrm{c})$ \\
\hline Astyris permodesta & 0 & 0.0 & $0.60(0.60)$ & 0.008 & 0 & 0.0 & \\
\hline Scaphopoda & & & & & & & \\
\hline Cadulus sp. & $1.67(0.49)$ & 0.018 & 0 & 0.0 & $2.00(0.41)$ & 0.024 & $0.0052(\mathrm{e})$ \\
\hline Cadulus tolmiei & 0 & 0.0 & 0 & 0.0 & $0.50(0.29)$ & 0.006 & \\
\hline PORIFERA & & & & & & & \\
\hline Unid. Porifera & $0.17(0.17)$ & 0.002 & 0 & 0.0 & $0.75(0.48)$ & 0.009 & \\
\hline ECHINODERMATA & & & & & & & \\
\hline Ophiuroidea & & & & & & & \\
\hline Unid. ophiuroid juv. & 0 & 0.0 & 0 & 0.0 & $0.50(0.50)$ & 0.006 & \\
\hline Ophiosphalma jolliense & $1.67(1.11)$ & 0.018 & 0 & 0.0 & 0 & 0.0 & \\
\hline Total number of ind. & 91.33 (11.93) & & $73.00(24.17)$ & & $84.75(9.59)$ & & \\
\hline Total number of ind. $\mathrm{m}^{-2}$ & $16891.68(2207.33)$ & & $13502.01(4470.17$ & & $15674.12(1774$ & & \\
\hline Number of species & $27.33(2.11)$ & & $12.40(2.16)$ & & $22.25(1.65)$ & & $0.0061(\mathrm{e})$ \\
\hline
\end{tabular}



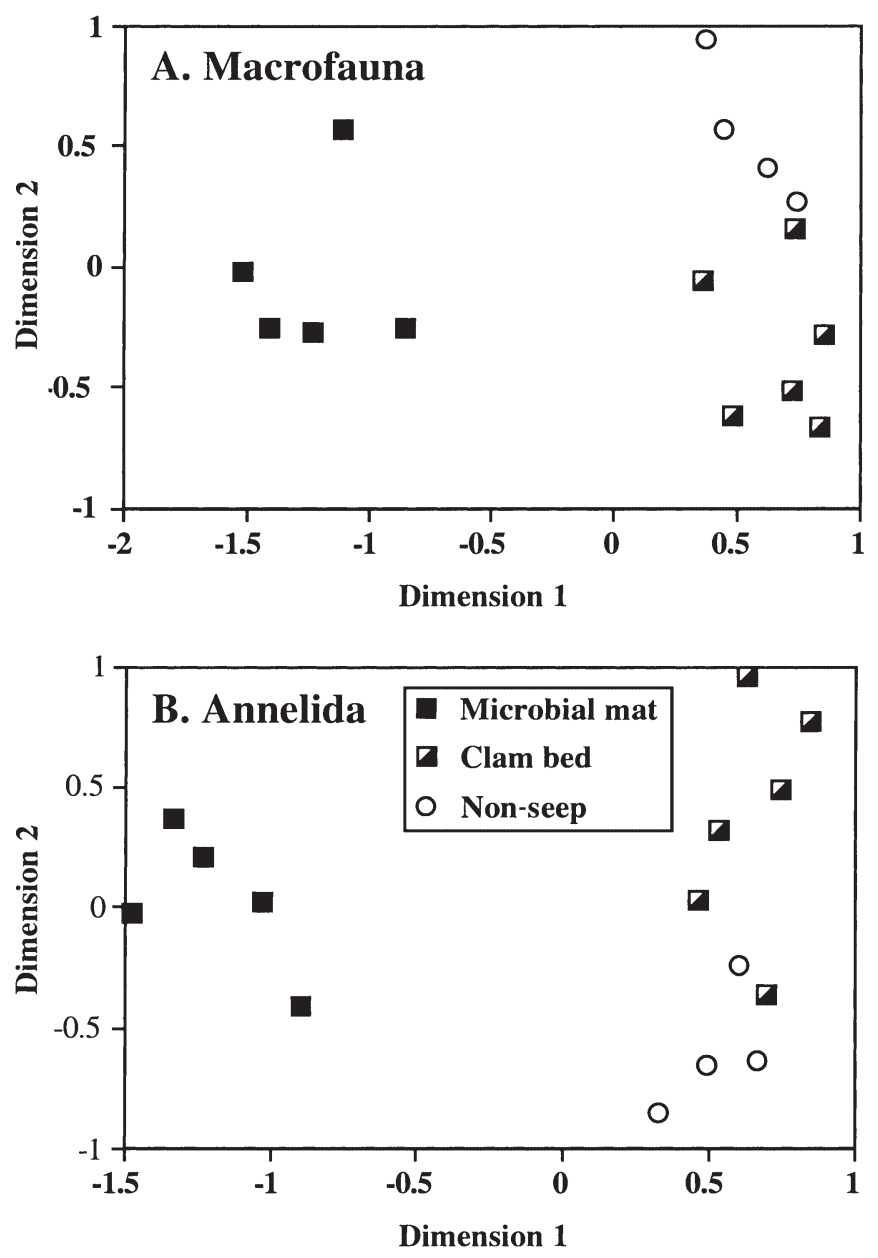

Fig. 6. MDS plot of macrofaunal assemblages in microbial mat, clam-bed and non-seep sediments. (A) Total macrofauna $($ stress $=0.09) ;(B)$ annelids (stress $=0.10)$

[p $=0.0002]$ and $10.6 \%$ [ $p=0.012]$, respectively) than found in microbial mat sediments. Tanaids comprised a greater fraction of the non-seep assemblage than of the clam bed assemblage (19.3 vs $9.6 \%)(p=0.039)$.

The microbial mat sediments appear quite distinct from the clam-bed and non-seep habitats when annelids are considered separately at the family level (Fig. 5B). Most annelids in the mat sediments were dorvilleid polychaetes $(92 \%) ; 87 \%$ of the identified dorvilleids belonged to 3 species in the genus Ophryotrocha. The only other species to comprise up to $2 \%$ of the annelids in the microbial mat habitat was Nephtys cornuta. Tubificid oligochaetes, capitellid, and paraonid polychaetes were the most common taxa in the clam bed and non-seep sediments (Fig. 5B; Table 1). No gutless oligochaetes were present at the Eel River site. The tubificid Tectidrilus cf. diversus comprised $9.3 \%$ of the clam bed macrofauna, but was absent from microbial mat and non-seep sediments. Other tubificid oligochaetes formed $7.8 \%$ of the non-seep macrofauna.

The microbial mat macrofaunal community was highly distinct from those of the clam-bed and nonseep habitats (Fig. 6A; ANOSIM: mat vs clam bed $\mathrm{p}=$ 0.002; mat vs non-seep $p=0.008$ ). The clam bed macrofaunal assemblage also differed from the nonseep community (ANOSIM, p = 0.010) (Fig. 6A). However, the microbial mat, clam-bed and non-seep assemblages exhibited similar within-habitat heterogeneity (SIMPER: 41, 35 and 41\% similarity, respectively). The annelid assemblage (Fig. 6B), exhibited habitat relationships nearly identical to those seen for total macrofauna (Fig. 6A). However, the clam-bed annelid assemblage exhibited slightly greater heterogeneity among samples (32\% within-group similarity) than the mat and non-seep annelid assemblages (both $45 \%$ within-group similarity) (SIMPER).

\section{Diversity patterns}

Macrofaunal species diversity exhibited habitatrelated heterogeneity, consistent with sulfide inhibition of species richness and evenness. The number of macrofaunal species per core was similar in the clam bed $(27.3 \pm 2.1)$ and non-seep sediments $(22.3 \pm 1.7)$ (Wilcoxon test: $\mathrm{p}=0.195)$, but significantly higher than in the microbial mat sediments $(12.4 \pm 2.2)$ (Wilcoxon test: $\mathrm{p}=0.007)$. For core data pooled by habitat, information $\left(H^{\prime} \log\right.$ base2 $)$ and rarefaction indices of diversity were highest in clam-bed sediments $\left[H^{\prime}=4.99 ; \mathrm{E}\left(\mathrm{S}_{100}\right)\right.$ $=36.0]$, lowest in microbial mat sediments $\left[H^{\prime}=2.50\right.$; $\left.\mathrm{E}\left(\mathrm{S}_{100}\right)=18.1\right]$, and intermediate within the non-seep sediments $\left[H^{\prime}=4.53 ; \mathrm{E}\left(\mathrm{S}_{100}\right)=30.0\right]$ (Fig. 7). $H^{\prime}$ calculated for each core was also significantly lower in microbial mat cores than in clam-bed or non-seep cores (Kruskal-Wallis: $\mathrm{p}=0.004$ ). Rank 1 dominance (R1D, top-ranked species) was highest for pooled samples in the microbial mat sediments (Ophryotrocha platykephale $62 \%$ ), and lower in the clam-bed (unidentified nemertean $13.4 \%$ ) and in non-seep sediments (unidentified tanaid 17.7\%) (Kruskal-Wallis: $\mathrm{p}=0.023$ ). However, macrofaunal evenness $\left(J^{\prime}\right)$ exhibited no significant differences among habitats (Kruskal-Wallis: $\mathrm{p}=0.156)$.

Annelid diversity exhibited patterns similar to those of the total macrofauna. The number of species per core (species richness, $S$ ) (Kruskal-Wallis: $\mathrm{p}=0.024$ ) and $H^{\prime}$ (Kruskal-Wallis: $\mathrm{p}=0.011$ ) differed among habitats, with microbial mat annelids exhibiting lowest diversity. Species richness and $H^{\prime}$ for annelids in clam-bed and non-seep microhabitats did not differ. Annelid evenness $\left(J^{\prime}\right)$ (Kruskal-Wallis: p = 0.422) and R1D (Kruskal-Wallis: $\mathrm{p}=0.256$ ) did not differ among habitats. 

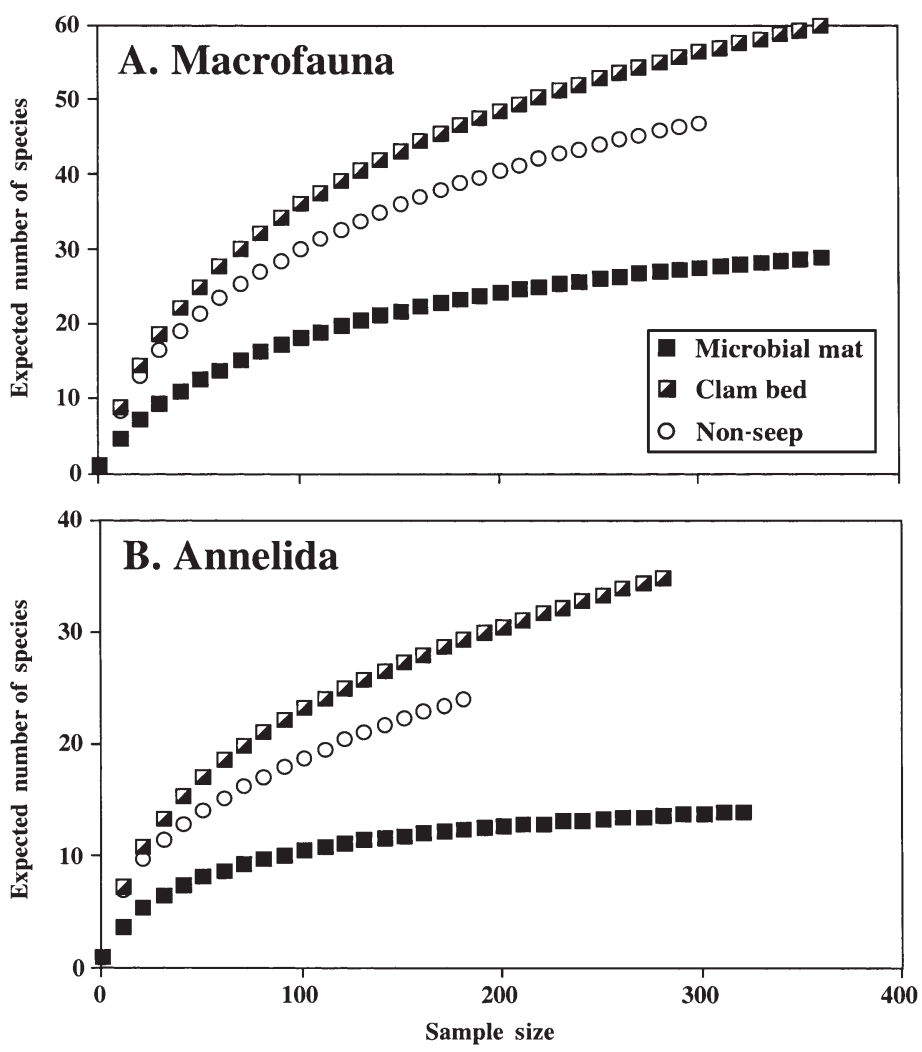

Fig. 7. Rarefaction curves illustrating species richness for pooled samples from microbial mat, clam-bed and non-seep sediments. (A) Total macrofauna; (B) annelids. Species richness values are slightly underestimated because Turbellaria were not identified to species level

\section{Vertical distribution of macrofauna and bacteria}

Habitat variation in vertical patterns

Vertical distributions of macrofauna varied among habitats. Macrofauna (mainly dorvilleids) were concentrated in the uppermost sediments in microbial mat cores, with $64 \%$ of macrofauna in the 0 to $1 \mathrm{~cm}$ layer and $91 \%$ in the top $2 \mathrm{~cm}$ (Figs. 8A \& 9). Only 48 and $40 \%$ of macrofauna were present in the top $1 \mathrm{~cm}$ of clam bed and non-seep sediments, respectively. A significantly greater fraction of the macrofaunal individuals was found below $2 \mathrm{~cm}$ in the non-seep sediments $(38 \%$ below $2 \mathrm{~cm}$ ) than in microbial mat sediments $(9 \%$ below $2 \mathrm{~cm}$ ) (arcsine percentage test, $\mathrm{p}<0.0001$ ), but clam-bed patterns $(29 \%$ below $2 \mathrm{~cm}$ ) did not differ from those in either of the other microhabitats ( $p=0.162$ ) (Fig. 8A). Macrofaunal biomass was concentrated in the uppermost $2 \mathrm{~cm}$ in all microhabitats (Fig. 8B). Among dorvilleid polychaetes, $46 \%$ of individuals were found from 2 to $10 \mathrm{~cm}$ in clam-bed sediments; less than $10 \%$ occurred below $2 \mathrm{~cm}$ in microbial mat sediments (Fig. 9).
Most annelid taxa that tend to dwell deeper in the nonseep sediment column (Paraonidae, Cossuridae, Cirratulidae, Tubificidae) exhibited a slight shallowing of their distribution in clam bed sediments and were restricted to the uppermost $1 \mathrm{~cm}$ (or were absent) in microbial mat sediments (Fig. 9). These patterns would be expected if sulfide avoidance controlled vertical distributions. Exceptions were found among capitellid, nephtyid and dorvilleid polychaetes; individuals of these taxa were found down to $5 \mathrm{~cm}$ in microbial mat cores (Fig. 9).

Filamentous sulfur bacteria were concentrated in the upper $1 \mathrm{~cm}$ in the mat sediments, but were present throughout the entire $10 \mathrm{~cm}$ sediment column (Fig. 10). The microbial mat biomass-distribution (Fig. 10B) was shifted upward relative to the filament counts (Fig. 10A), indicating that filaments were larger near the sediment surface. Clam-bed and non-seep sediments also contained living sulfur bacterial filaments concentrated between 1 and $5 \mathrm{~cm}$ (Fig. 10).

\section{Sulfide and faunal vertical distributions}

The typical relationship between sulfide and animal abundance in this study was L-shaped, with a range of
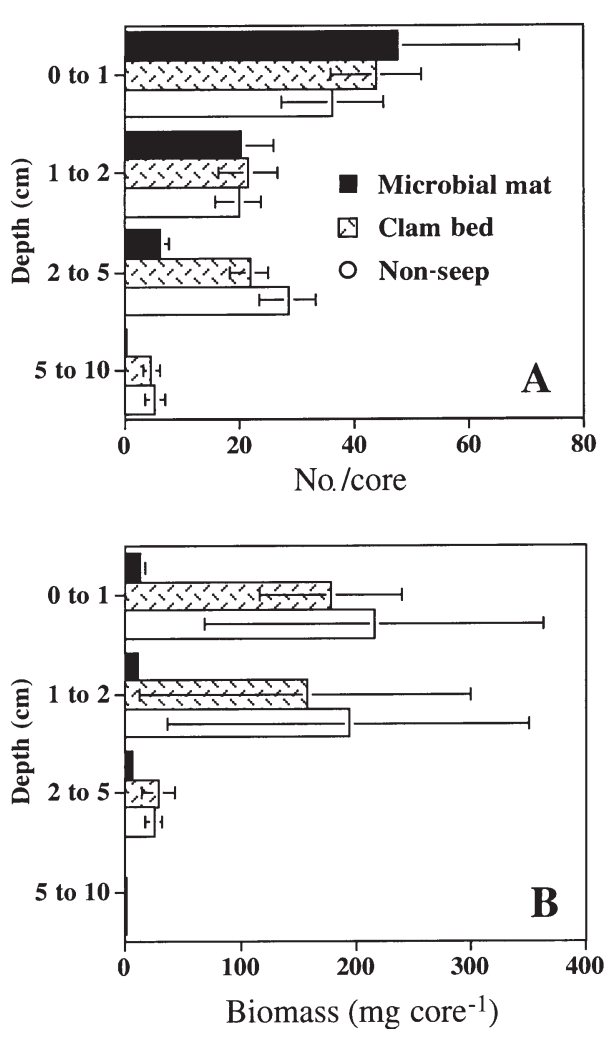

Fig. 8. Vertical distribution of (A) macrofaunal density and (B) macrofaunal biomass. All data are for fauna retained on $300 \mu \mathrm{m}$ mesh. Core surface area $=54.1 \mathrm{~cm}^{2} ;$ depth $=10 \mathrm{~cm}$ 

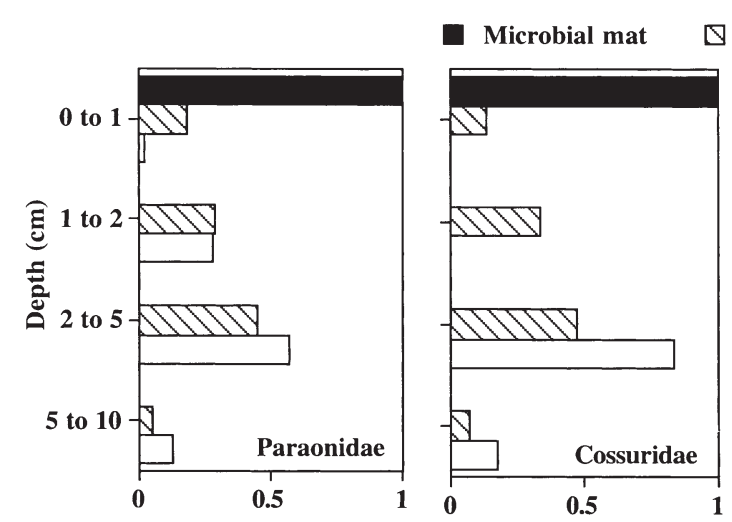

$\triangle$ Clam bed $\square$ Non-seep
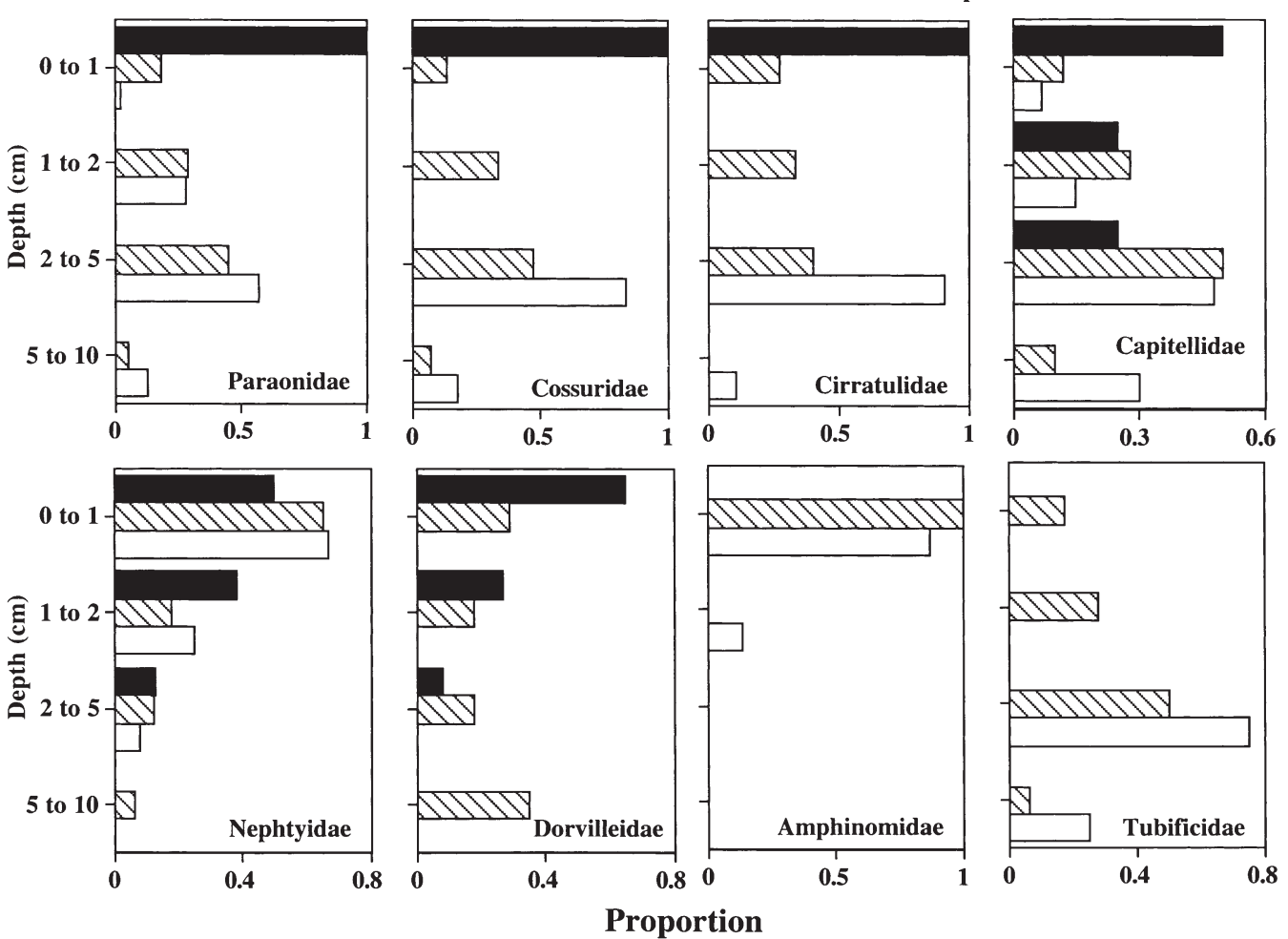

Fig. 9. Vertical distribution of common annelids in microbial mat, clambed and non-seep habitats. Data normalized such that values in each vertical fraction represent the proportion of total individuals in each family collected for a specific microhabitat

densities at zero sulfide levels and zero or near-zero densities at higher sulfide levels. This 'L shaped' pattern was observed for cirratulid and paranoid polychaetes, nemerteans, amphipods, tanaids and gastropods across all settings (Fig. 11). Slight sulfide tolerance was evident among the polychaetes Nephtys cornuta and Mediomastus spp. (Fig. 11); low densities were observed at 1 to $10 \mathrm{mM}$ sulfide. Counts of total macrofauna, sulfide-oxidizing filamentous bacteria, dorvilleid polychaetes and bivalves (mainly Vesicomya pacifica) exhibited highest densities at moderate sulfide levels (1 to $5 \mathrm{mM}$ ) and lower densities at 5 to $14 \mathrm{mM}$ sulfide (Fig. 11). Numerous taxa in clam bed cores appeared to reside in the upper 0 to $5 \mathrm{~cm}$ of the sediment column, where sulfide concentrations were near zero.

The distribution of individual dorvilleid species in relation to sulfide concentration indicates that different dorvilleid species prefer mat and clam-bed sediments and that, within a microhabitat, some species partition the sediments vertically (Fig. 12). In 1 microbial mat core, Ophryotrocha platykephale appeared to prefer sulfide concentrations $<4 \mathrm{mM}$, while 2 other species (Ophryotrocha sp. and Pseudophryotrocha cf. serrata) were most abundant at sulfide concentrations of 4 to 13 mM. In clam-bed sediments, Parougia sp. n was present mainly in the upper $5 \mathrm{~cm}$, where sulfide concentrations were low or zero, and Exallopus sp. a was found below $5 \mathrm{~cm}$ where sulfide concentration was
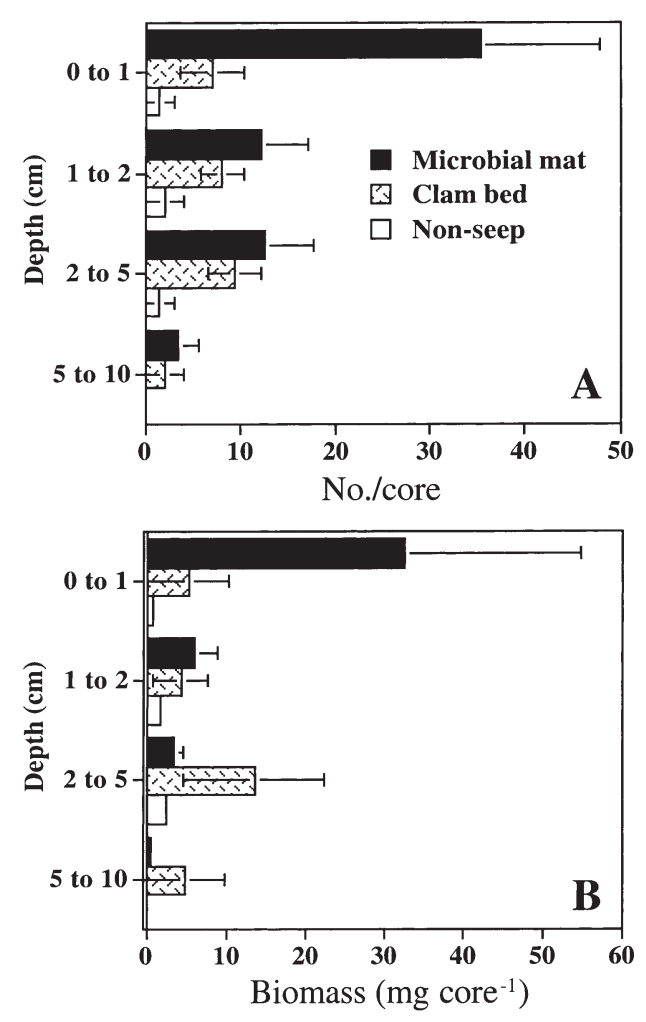

Fig. 10. Filamentous sulfur bacteria. (A) Counts; (B) biomass. Data are for filaments retained on $300 \mu \mathrm{m}$ mesh. Core surface area $=54.1 \mathrm{~cm}^{2} ;$ depth $=10 \mathrm{~cm}$ 

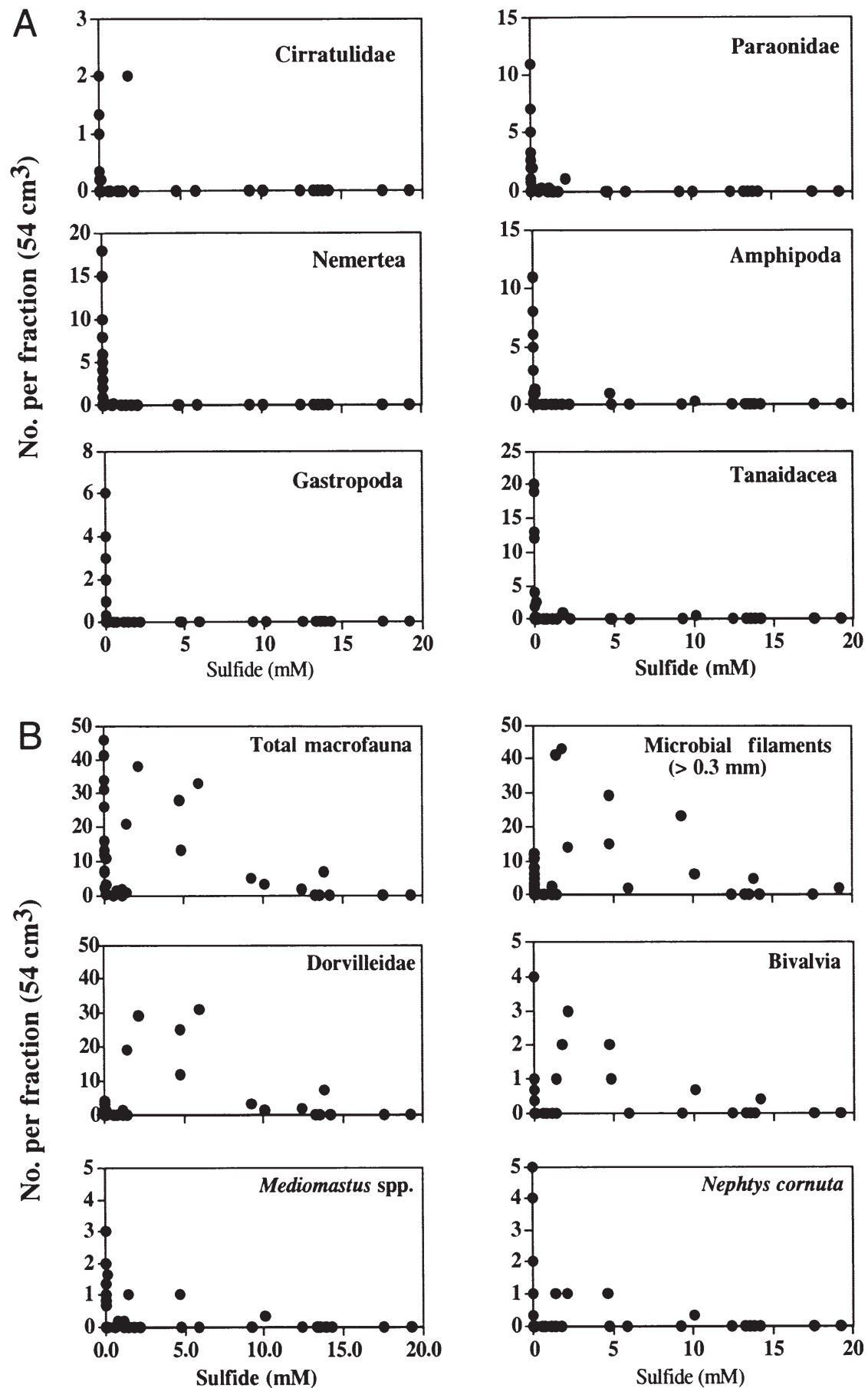

Fig. 11. Scatter-plots of macrofaunal density as a function of sulfide concentration for data from $1 \mathrm{~cm}$ thick core sections, all microhabitats combined. (A) Taxa exhibiting sulfide avoidance; (B) taxa exhibiting sulfide tolerance

\section{DISCUSSION}

\section{Seep habitats}

The habitat-scale features (1 to $100 \mathrm{~m}$ ) of the Eel River upper-slope seeps differ from those of other seep sites in the northeast Pacific. On the Cascadia Margin and in Monterey Bay, methane seep communities display a concentric zonation, with bacterial mats in the center surrounded by different vesicomyid clam or solemyid bivalve communities exhibiting different tolerances to sulfide (Sahling et al. 2002, W. Ziebis unpubl. data). On Hydrate Ridge, fluid flow appears to be mainly confined to fewer but more mature and vigorous sites (Tryon et al. 2002), on which large carbonate blocks (chemoherms) have grown over time (Bohrmann et al. 1998). In contrast, the methane seep environments on the Eel River slope form small, visually distinctive patches of Vesicomya pacifica communities and mats of filamentous sulfur bacteria, but they are not typically continuous (Figs. 1 \& 2). In Monterey Bay, the species Calyptogena (Vesicomya) pacifica is associated with lower sulfide concentrations than $C$. kilmeri (Barry et al. 1997). On the Cascadia Margin, $C$. pacifica and C. kilmeri communities were encircled by Acharax sp. communities along horizontal sulfide gradients (Sahling et al. 2002). C. kilmeri and Acharax sp. were not observed at the Eel River seeps.

It is possible that highly specific sulfide concentrations, vertical sulfide gradients and fluid expulsion environments are responsible for the formation of the different Calyptogena kilmeri and Acharax sp. assemblages. The Eel River sulfide concentrations may have been too low in Vesicomya pacifica beds and too high in microbial mats for $C$. kilmeri to thrive. It is higher (Fig. 12). Additional fine-scale $(<1 \mathrm{~cm})$ measurements of dorvilleid abundance and sulfide concentrations in the same sediments are needed to determine whether these patterns are representative and repeatable at different times and places. interesting that the maximum sulfide concentrations measured in Oregon margin clam-bed sediments were similar to those of the Oregon Beggiatoa spp. community (Sahling et al. 2002), whereas at the Eel River site, the sulfide concentration measured in intact cores retrieved from the microbial mat and clam-bed habitats 


\section{A. Microbial mat}

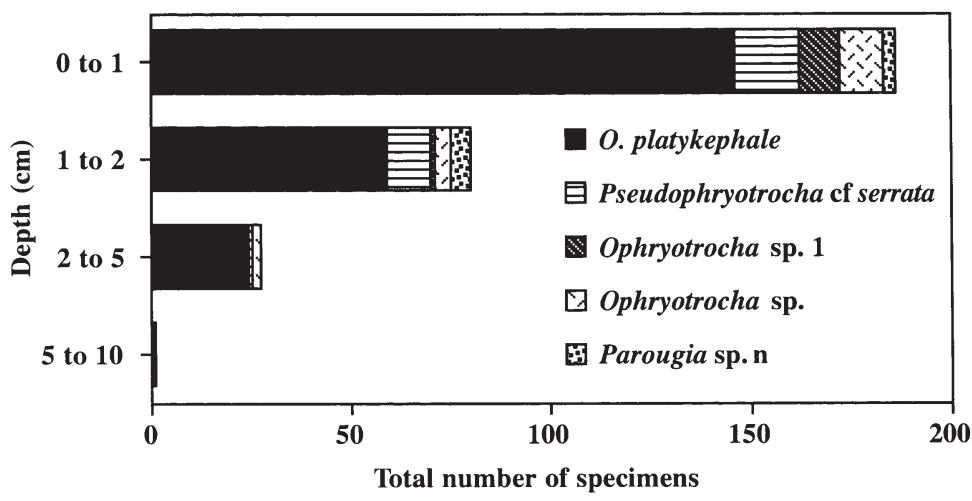

B. Clam bed

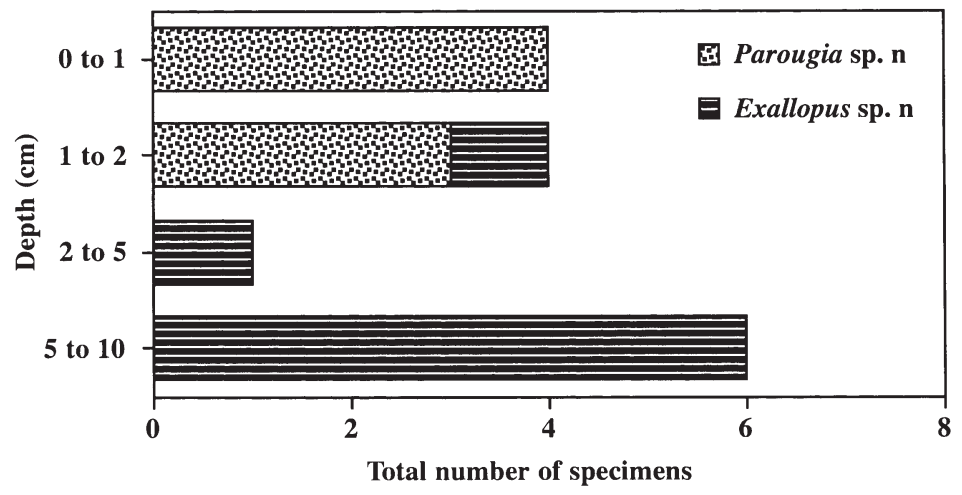

Fig. 12. Vertically resolved plots of dorvilleid species distributions summed across all cores sampled within (A) microbial mat and (B) clam-bed sediments

exhibited order-of-magnitude concentration differences and different vertical distributions (Fig. 4). The sulfide profiles observed by Sahling et al. (2002) in sediments of the Oregon Calyptogena ( $V$. pacifica) community resemble those observed in $V$. pacifica beds at Eel River in having low sulfide concentrations in the upper $5 \mathrm{~cm}$ (Fig. 4), but increased to maximum concentrations of 15 to $25 \mathrm{mM}$. These values are more characteristic of the Eel River microbial mats, where upward transport of pore fluids occurs (Fig. 3), than the C. pacific beds (maxima of 1 to $2 \mathrm{mM}$ sulfide), where sulfide production occurs locally by sulfate reduction in a defined sediment horizon ( 6 to $9 \mathrm{~cm}$ ) below the zone inhabited by the clams (Ziebis et al. 2002). The 0.1 to $0.2 \mathrm{mM}$ sulfide concentrations present in subsurface sediments of the Oregon Acharax sp. assemblage (Sahling et al. 2002) were only slightly higher than we observed in non-seep sediments on the Eel River margin.

\section{Habitat variability}

Our sampling revealed a highly patchy system, in which sulfide concentration is correlated with signifi- cant changes in community structure that occur on small scales both horizontally and vertically. The distinctive nature of the microbial mat assemblage observed in this study is almost certainly due to the attendant high sulfide concentrations (Fig. 4) that result from a high magnitude of vertical upward transport and flux into the overlying water (Fig. 3). However, the limited spatial coverage of our microbial mat measurements prevents generalization to all mat settings in the area. The sulfide-laden fluids that support the high abundances of filamentous sulfur bacteria present at the sediment-water interface are generated by high rates of sulfate reduction supposedly coupled to anaerobic methane oxidation (Boetius et al. 2000, Hinrichs et al. 2000, Orphan et al. 2001). Rates of sulfate reduction and methane oxidation in these Eel River microbial mat sediments were significantly higher than in clam-bed or non-seep sediments (Ziebis et al. 2002).

The dominance of dorvilleid polychaetes in highly sulfidic sediments is not altogether unexpected. Dorvilleids have been observed in sulfidic shallow-water settings including pulp mill and sewage outfalls (Paavo et al. 2000). They are also dominant in hydrothermal mounds in Guaymas Basin (Grassle et al. 1985, Petrecca \& Grassle 1987), in sediments surrounding whale falls (Smith et al. 1998, A. Bacco \& C. Smith unpubl. data), at seeps on the Oregon margin (Sahling et al. 2002, L. Levin et al. unpubl. data) and in the Gulf of Mexico (C. Robinson et al. unpubl. data), and in oxygen minimum-zone sediments off Mexico (Levin et al. 1991) and northern Chile (L. Levin \& V. Gallardo unpubl. data). The dominant species, Ophryotrocha platykephale, was first reported from hydrothermal vents (Blake \& Hilbig 1990). The co-occurrence of 6 dorvilleid species, 3 of them congeners within the genus Ophryotrocha, is highly unusual however, and raises questions about habitat preferences and niche partitioning.

In shallow water, the genus Ophyrotrocha contains a large number of morphologically similar species that exhibit a broad range of reproductive strategies and are distinguishable with molecular tools (Dahlgren et al. 2001). It is possible that the sulfidic environment found in seep sediments eliminates competitors and predators, providing evolutionary release for dorvilleids. We hypothesize that strong geochemical gradients and unusual microbial food sources associated with methane seeps promote evolutionary differentiation in this genus, and provide the habitat heterogeneity required to support closely related species. Direct gut observations and stable isotopic data suggest that the different dorvilleid species at the Eel River seeps 
have widely varying diets, ranging from heterotrophic consumption of phytoplankton-derived organic matter or filamentous sulfur bacteria, to possible possession of symbiotic, sulfide-oxidizing bacteria (L. Levin unpubl. data). Dorvilleid polychaetes at seeps in the Gulf of Alaska and Oregon exhibit exceptionally light $\delta^{13} \mathrm{C}$ signatures $(-90 \%,-73 \%)$, suggesting selective consumption of carbon derived from anaerobic methane oxidation (Levin \& Michener 2002).

Dorvilleid polychaetes are clearly the most sulfidetolerant of the taxa present on the Eel River slope (Fig. 11). Only Vesicomya sp. and sulfur bacterial filaments exhibited similar tolerance to sulfide concentrations of 5 to $10 \mathrm{mM}$ (Fig. 11). It is not known whether the sulfide tolerance of dorvilleids results from sulfide insensitivity or from well-developed detoxification mechanisms (or both) (Grieshaber \& Volkel 1998). The distinct horizontal (habitat) and vertical (microhabitat) distributions of individual dorvilleid species (Fig. 12), suggest that they may be capable of fine-scale selection for specific sulfide conditions.

The general similarity of clam-bed and non-seep macrofauna assemblages observed at the Eel River seeps (Figs. 6 \& 7) may reflect their similar hydrologic and porewater geochemical environments down to 4 to $5 \mathrm{~cm}$ (Figs. $3 \& 4$ ). This is the zone where most of the macrofauna were found and where sulfide concentration was lowest.

A notable difference between the clam-bed and non-seep assemblages was higher overall species richness and greater relative abundance of selected macrofaunal species. We propose that the higher macrofaunal diversity in Vesicomya pacifica beds occurs because the clam bed environment represents an ecotone. Clam pumping activity brings oxygen and seawater sulfate down into the sediment, creating an oxygenated habitat in the upper sediments (Fig. 4), and stimulating sulfate reduction and productive sulfide-oxygen interface zones. $V$. pacifica bed sediments support both non-seep taxa, experiencing relatively sulfide-free porewaters in the upper sediment column, and deeper-dwelling species that benefit from sulfide-oxygen interfaces. The sulfide-oxygen interface group includes the oligochaete Tectidrilus diversus, as well capitellid, cossurid and paranoid polychaetes, taxa for which $\geq 50 \%$ of individuals are found in the 2 to $5 \mathrm{~cm}$ fraction (Fig. 9). These groups typically exhibit subsurface density maxima (Blake 1994), but the reasons are not known. Selected species of Capitellidae prefer sulfidic habitats (Gamenick et al. 1998a,b) and grow better in the presence of sulfide (Clough \& Lopez 1993, Tsutsumi et al. 2001). In the Eel River clam beds, the interface taxa may be taking advantage of higher microbial biomass in this zone due to increased sulfide oxidation and sulfate reduction activity (Ziebis et al. 2002), or may merely be more tolerant of sulfides and reside deep in the sediment column to escape predation and competition with other species. Unusually light $\delta^{13} \mathrm{C}$ values have been measured at the Eel River seeps for some of these subsurface, interface taxa (e.g., tubificid oligochaetes $\left(\delta^{13} \mathrm{C}=-39.7\right.$ to $\left.-34.8 \%\right)$, V. pacifica ( -36.4 to $-36.7 \%$ ) , the dorvilleid Parougia sp. (-35.9\%o), a maldanid polychaete $(-31.5 \%)$, and the capitellid polychaete Mediomastus californiensis $(-30.5 \%$ ), indicating that they derive nutrition from chemosynthetically fixed carbon sources (Levin \& Michener 2002). Benthic foraminifera collected previously from Eel River Vesicomya pacifica beds also exhibited high infaunal densities in the upper $5 \mathrm{~cm}$ and distinct distributions compared to conspecifics found in adjacent sediments. Differences in carbonate test $\delta^{13} \mathrm{C}$ signatures of these foraminifera also indicated probable ecological and biological differences among co-occurring species (Rathburn et al. 2000)

\section{Vertical patchiness and role of sulfide}

Results from this study and previous work (e.g. Torres et al. 2002) suggest that the vertical distribution of sulfide is largely controlled by fluid flow and, where clams are present, by their active pumping. Average flow rates of $10 \mathrm{~cm} \mathrm{yr}^{-1}$ (Fig. 3) were sufficient to inhibit inflow and extend the sulfide boundary to the sediment surface in the microbial mat habitat (Fig. 4). It is likely that the animal communities we have described reflect geochemical conditions integrated over time. The biological significance of temporal flow variability, particularly the absence of flow for extended periods of time as recorded here at the microbial mat sites, merits further attention.

The distribution of macrofaunal individuals relative to local sulfide concentrations reveals that most taxa avoid sulfide concentrations $>1 \mathrm{mM}$ (Fig. 11). Even in habitats known to contain significant concentrations of sulfide (e.g. Vesicomya pacifica beds), most infauna occupy that portion of the sediment column that is relatively sulfide-free. This emphasizes the importance of resolving both animals and porewater geochemistry within the sediment column on fine $(1 \mathrm{~cm}$ or less) vertical scales when trying to understand the relationships between the two. In previous studies, cores have been taken either for sulfide analyses or for analysis of macrofauna composition, with little attention paid to the vertical distribution of macrofauna. A more complete understanding of how community structure relates to sulfide gradients emerges when fine-scale vertical analyses of sulfide and animal distributions are performed on identical cores. 
Acknowledgements. The success of our field program was due to the dedicated efforts of the captain and crews of the RV 'Thompson', DSRV 'Jason' and DSRV 'Oceanic Explorer'. Their persistence tremendously facilitated our work. We also thank Shelly Walther and the many other scientists and students who worked tirelessly at sea with us during TN Legs 118 and 122. Special thanks are extended to L. Lovell and the Scripps Benthic Collections for assistance with identifications. Additional taxonomic assistance was provided by Drs. Brigitte Hilbig, Doug Diener, Tim Stebbins, John Ljubenkov and Megan Lilly. The manuscript was improved by comments from C. Peterson and 2 anonymous reviewers. We gratefully acknowledge support for this research from grant 00-0050 awarded by the NOAA West Coast National Undersea Research Center.

\section{LITERATURE CITED}

Alexander CR, Simoneau AM (1999) Spatial variability in sedimentary processes on the Eel continental slope. Mar Geol 154:243-254

Aller RC (1982) The effects of macrobenthos on chemical properties of marine sediment and overlying water. In: Mc Call PL, Tevesz MJ (eds) Animal-sediment relations. Plenum Press, New York, p 53-102

Barry JP, Greene HG, Orange DL, Baxter $\mathrm{CH}$ and 5 others (1996) Biologic and geologic characteristics of cold seeps in Monterey Bay, California. Deep-Sea Res 43:1739-1762

Barry JP, Kochevar RE, Baxter CH (1997) The influence of pore-water chemistry and physiology in the distribution of vesicomyid clams at cold seeps in Monterey Bay: implications for patterns of chemosynthetic community organization. Limnol Oceanogr 42:318-328

Bernhard JM, Buck KR, Barry JP (2001) Monterey Bay coldseep biota: assemblages, abundance, and ultrastructure of living foraminifera. Deep-Sea Res Part I Oceanogr Res Pap 48:2233-2249

Blake JA (1994) Vertical distribution of benthic infauna in continental slope sediments off Cape Lookout, North Carolina. Deep-Sea Res II 41:919-927

Blake JA, Hilbig B (1990) Polychaeta from the vicinity of deep-sea hydrothermal vents in the eastern Pacific. II. New species and records from the Juan de Fuca and Explorer Ridge systems. Pac Sci 44:219-253

Boetius AK, Ravenschlag K, Schubert CJ, Rickert D and 6 others (2000) A marine microbial consortium apparently mediating anaerobic oxidation of methane. Nature 407: 623-626

Bohrmann G, Greinert J, Suess E, Torres M (1998) Authigenic carbonates from the Cascadia subduction zone and their relation to gas hydrate stability. Geology 26:657-650

Buck KR, Barry JP (1998) Monterey Bay cold seep infauna: quantitative comparison of bacterial mat meiofauna with non-seep control sites. Cah Biol Mar 39:333-335

Clarke KR, Warwick RM (1994) Change in marine communities: an approach to statistical analysis and interpretation. Natural Environmental Research Council, United Kingdom and Plymouth Marine Laboratory, Plymouth, UK

Cline JD (1969) Spectrophotometric determination of hydrogen sulfide in natural waters. Limnol Oceanogr 14: $454-458$

Clough LM, Lopez GR (1993) Potential carbon sources for the head down deposit feeding polychaete Heteromastus filiformis. J Mar Res 51:595-616

Dahlgren TG, Akesson B, Schander C, Halanych K, Sundberg P (2001) Molecular phylogeny of the model annelid
Ophryotrocha. Biol Bull (Woods Hole) 201:193-203

Freytag JK, Girgius PR, Bergquist DC, Andras JP, Childress JJ, Fisher CR (2001) A paradox resolved: sulfide acquisition by roots of seep tubeworms sustains net chemoautotrophy. Proc Natl Acad Sci USA 98:13408-13413

Gamenick I, Abbiati M, Giere O (1998a) Field distribution and sulphide tolerance of Capitella capitata (Annelida: Polychaeta) around shallow water hydrothermal vents off Milos (Aegean Sea). A new sibling species? Mar Biol 130: $447-453$

Gamenick I, Vismann B, Grieshaber MK, Giere O (1998b) Ecophysiological differentiation of Capitella capitata (Polychaeta). Sibling species from different sulfidic habitats. Mar Ecol Prog Ser 175:155-166

Goffredi SK, Hurtado L, Hallam S, Vrijenhoek RC (2003) Evolutionary relationships of deep-sea vent and cold seep clams (Mollusca: Vesicomyidae) of the 'pacifica/lepta' species complex. Mar Biol 142:311-320

Grassle JF, Brown-Leger S, Morse-Porteous L, Petrecca R, Williams I (1985) Deep-sea fauna of sediments in the vicinity of hydrothermal vents. Bull Biol Soc Wash 6:443-452

Grieshaber MK, Volkel S (1998) Animal adaptations for tolerance and exploitation of poisonous sulfide. Annu Rev Physiol 60:33-53

Hinrichs KU, Summons RE, Orphan V, Sylva SP, Hayes J M (2000) Molecular and isotopic analysis of anaerobic methane-oxidizing communities in marine sediments. Org Geochem 31:1685-1701

Hovland M (2002) On the self-sealing nature of marine seeps. Cont Shelf Res 22:2387-2394

Hurlbert SH and CM Lombardi (2003) Design and analysis uncertain intent, uncertain result. Ecology 83:80-82

Jeroschewsky P, Steuckart C, Kuehl M (1996) An amperometric microsensor for the determination of $\mathrm{H}_{2} \mathrm{~S}$ in aquatic environments. Anal Chem 68:4351-4357

Jørgensen BB, Revsbech NP (1985) Diffusive boundary layers and the oxygen uptake of sediments and detritus. Limnol Oceanogr 30:111-122

Jørgensen BB and Revsbech NP (1989) Oxygen uptake, bacterial distribution and carbon-nitrogen-sulphur cycling in sediments from the Baltic Sea North Sea transition. Ophelia 31:29-49

Kennicutt MC II, Brooks JM, Bidigare RR, McDonald SJ, Adkison DL, Macko SA (1989) An upper slope 'cold' seep community: Northern California. Limnol Oceanogr 34: $635-640$

Kuehl M, Steukart C, Eickert G, Jeroschewsky P (1998) A $\mathrm{H}_{2} \mathrm{~S}$ microsensor for profiling biofilms and sediments: application in an acidic lake sediment. Aquat Microb Ecol 15: 201-209

Kulm LD, Suess E, Moore JC, Carson B and 10 others (1986) Oregon subduction zone: venting, fauna and carbonates. Science 231:561-566

Leithold EL, Hope RS (1999) Deposition and modification of a flood layer on the northern California shelf: lessons from and about the fate of terrestrial particulate organic carbon. Mar Geol 154:183-195

Levin LA, Michener R (2002) Isotopic evidence of chemosynthesis-based nutrition of macrobenthos: the lightness of being at Pacific methane seeps. Limnol Oceanogr 47: 1336-1345

Levin LA, Thomas CL,Wishner K (1991) Control of deep-sea benthic community structure by oxygen and organic-matter gradients in the eastern Pacific Ocean. J Mar Res 49: $763-800$

Levin LA, James DW, Martin CM, Rathburn AE, Harris LH, Michener RH (2000) Do methane seeps support distinct 
macrofaunal assemblages? Observations on community structure and nutrition from the northern California slope and shelf. Mar Ecol Prog Ser 208:21-39

Magurran AE (1988) Ecological diversity and its measurement. Princeton University Press, Princeton, NJ

McAleece N, Lambshead J, Paterson G, Gage J, Harris P, Lamont P (1997) BioDiversity Pro. Natural History Museum and Scottish Association For Marine Science

Orphan VJ, Hinrichs KU, Ussler III W, Paull CK, Taylor LT, Sylva SP, Hayes J M, DeLong EF (2001) Comparative analysis of methane-oxidizing archaea and sulfate-reducing bacteria in anoxic marine sediments. Appl Environ Microbiol 64: 1922-1934

Paavo B, Bailey-Brock JH, Åkesson B (2000) Morphology and life history of Ophryotrocha adherens sp. nov. (Polychaeta, Dorvilleidae). Sarsia 85:251-264

Petrecca RF, Grassle JF (1987) Notes on fauna from several deep-sea hydrothermal vent and cold seep soft-sediment communities. In: McMurray GR (ed) Gorda Ridge, a seafloor spreading center in the United States' exclusive economic zone. Springer-Verlag, New York, p 279-283

Quinn GP, MJ Keough (2002) Experimental design and data analysis for biologists. Cambridge University Press, New York

Rathburn AE, Levin LA, Held ZA, Lohmann KC (2000) Benthic foraminifera associated with cold methane seeps on the Northern Californian margin: ecology and stable isotopic composition. Mar Micropaleontol 38:247-266

Revsbech NP (1989) An oxygen microelectrode with a guard cathode. Limnol Oceanogr 34:472-476

Sahling H, Rickert D, Lee RW, Linke P, Suess E (2002) Macrofaunal community structure and sulfide flux at gas hydrate deposits from the Cascadia convergent margin. Mar Ecol Prog Ser 231:121-138

Sibuet M, Olu K (1998) Biogeography, biodiversity and fluid dependence of deep-sea cold-seep communities at active and passive margins. Deep-Sea Res II 45:517-567

Smith CR, Maybaum HL, Baco AR, Pope RH, Carpenter SD, Yager PL, Macko SA, Deming JW (1998) Sediment community structure around a whale skeleton in the deep Northeast Pacific: macrofaunal, microbial and bioturbation effects. Deep-Sea Res II 45:335-364

Sokal RR, Rohlf FJ (1969) Biometry. The principles and practice of statistics in biological research. WH Freeman \& Co, San Francisco

Suess E, Whiticar MJ (1989) Methane-derived $\mathrm{CO}_{2}$ in pore

Editorial responsibility: Charles Peterson (Contributing Editor), Morehead City, North Carolina, USA water fluids expelled from the Oregon subduction zone. Palaeogeogr Palaeoclimatol Palaeoecol 71:119-136

Suess E, Bohrman G, von Huene R, Linke P, Wallmann $K$, Lammers S, Sahling H (1998) Fluid venting in the eastern Aleutian subduction zone. J Geophys Res 103:2597-2614

Torres ME, McManus J, Hammond D, de Angelis MA and 5 others (2002) Fluid and chemical fluxes in and out of sediments hosting hydrate deposits on Hydrate Ridge, OR, I: Hydrological provinces, Earth Planet Sci Lett 201:525-540

Tryon MD, KM Brown (2001) Complex flow patterns through Hydrate Ridge and their impact on seep biota. Geophysical Res Lett 28:2863-2866

Tryon MD, Brown KM, Dorman LM, Sauter A (2001) A new benthic aqueous flux meter for very low to moderate discharge rates. Deep-Sea Res I 48:2121-2146

Tryon MD, Brown KM, Torres ME (2002) Fluid and chemical fluxes in and out of sediments hosting hydrate deposits on Hydrate Ridge, OR, II: Hydrological processes, Earth Planet Sci Lett 201:541-557

Tsutsumi H, Wainright S, Montani S, Saga M, Ichihara S, Kauhiro K (2001) Exploitation of a chemosynthetic food resource by the polychaete Capitella sp. I. Mar Ecol Prog Ser 216:119-127

Valentine, DL (2002) Biogeochemistry and microbial ecology of methane oxidation in anoxic environments: a review. Antonie Leeuwenhoek 81:271-282

Van Dover CL, Aharon P, Bernhard JM, Caylor E and 15 others (2003) Blake Ridge methane seeps: Characterization of a soft sediment, chemosynthetically based ecosystem. Deep-Sea Res I 50:281-300

Wallmann K, Linke P, Suess E, Bohrmann G and 6 others (1997) Quantifying fluid flow, solute mixing and biogeochemical turnover at cold vents of the eastern Aleutian subduction zone. Geochim Cosmochim Acta 61: 5209-5219

Wheatcroft RA (2000) Oceanic flood sedimentation: a new perspective. Contin Shelf Res 20:2059-2066

Yun JW, Orange DL, Field ME (1999) Subsurface gas offshore of northern California and its link to submarine geomorphology. Mar Geol 154:357-368

Ziebis W, Levin LA, Boetius A, Richnow HH, Bartlett DH (2002) Comparison of clam bed and microbial mat habitats at Eel River methane seeps, Northern California Margin: microbiological, geochemical and biological interactions. EOS Trans Am Geophys Un AGU 83 Ocean Sciences Meet Suppl Abstr OS12H-02

Submitted: February 16, 2003; Accepted: July 21, 2003

Proofs received from author(s): December 8, 2003 